\title{
Water-Soluble lonic Characteristics of Aerosols in the Marine Boundary Layer over the Yellow Sea during the KORUS-AQ Campaign
}

\author{
Joo Wan Cha ${ }^{1}$ (D) $\cdot$ Beomchel Shin ${ }^{2} \cdot$ Hee-Jung Ko ${ }^{1} \cdot$ Yun Kyu Lim ${ }^{1} \cdot$ Sang-Boom Ryoo ${ }^{1}$
}

Received: 7 April 2019 / Revised: 17 September 2019 / Accepted: 30 September 2019 / Published online: 29 November 2019

(C) The Author(s) 2019

\begin{abstract}
Major compositions of water-soluble ionic species in particulate matter less than 10 and $2.5 \mu \mathrm{m}$ in diameter $\left(\mathrm{PM}_{10}\right.$ and $\mathrm{PM}_{2.5}$, respectively) over the Yellow Sea were collected during the Korea-United States Air Quality (KORUS-AQ) campaign in 2016 onboard the research vessel Gisang 1. The secondary ionic species $\left(\mathrm{NH}_{4}{ }^{+}, \mathrm{nss}_{-} \mathrm{SO}_{4}{ }^{2-}\right.$, and $\left.\mathrm{NO}_{3}{ }^{-}\right)$in $\mathrm{PM}_{10}$ and $\mathrm{PM}_{2.5}$ accounted for $84 \%$ and $89 \%$ of the total analyzed species. $\mathrm{NH}_{4}{ }^{+}$was strongly correlated with non-sea salt (nss) $\mathrm{SO}_{4}{ }^{2-}\left(\mathrm{nss}_{-} \mathrm{SO}_{4}{ }^{2-}\right.$ ) in $\mathrm{PM}_{10}$ and $\mathrm{PM}_{2.5} ; \mathrm{NO}_{3}{ }^{-}$was closely correlated with $\mathrm{Na}^{+}, \mathrm{Mg}^{2+}$, and nss-Ca ${ }^{2+}$ in $\mathrm{PM}_{10}$ and $\mathrm{NH}_{4}{ }^{+}$in $\mathrm{PM}_{2.5}$. High mass concentrations of methane sulfonic acid (MSA, $\mathrm{CH}_{3} \mathrm{SO}_{3}{ }^{-}$), the main source of natural sulfates over the Yellow Sea, were observed. The concentrations of MSA were found to show an increasing trend over the Yellow Sea in recent years. Biogenic sulfur contributions to the total nss- $\mathrm{SO}_{4}{ }^{2-}$ (MSA/nss-SO ${ }_{4}{ }^{2-}$ ratio) over the Yellow Sea ranged from $1.4 \%$ to $9.2 \%$ in $\mathrm{PM}_{10}$ and from $0.68 \%$ to $9.5 \%$ in $\mathrm{PM}_{2.5}$ during the cruise. Thus, biogenic nss- $\mathrm{SO}_{4}{ }^{2-}$ must be included, especially in the spring and early summer seasons, when biological activities are elevated in Northeast Asia. We classified the high aerosol mass concentration cases such as Asian dust and haze cases. In Asian dust cases, the ratio of $\mathrm{NO}_{3}{ }^{-}$to nss- $\mathrm{SO}_{4}{ }^{2-}$ in the aerosols showed that mobile (stationary) sources mainly affected $\mathrm{PM}_{10}\left(\mathrm{PM}_{2.5}\right)$. The major chemical species for Asian dust cases over the Yellow sea were $\mathrm{CaCO}_{3}, \mathrm{Ca}\left(\mathrm{NO}_{3}\right)_{2}, \mathrm{Mg}\left(\mathrm{NO}_{3}\right)_{2}$, $\mathrm{Na}\left(\mathrm{NO}_{3}\right)_{2}$, and sea salt. In haze cases over the Yellow sea, the contributions from stationary sources are high and the major species were $\left(\mathrm{NH}_{4}\right)_{2} \mathrm{SO}_{4}$ and $\mathrm{NH}_{4} \mathrm{NO}_{3}$ in $\mathrm{PM}_{10}$ and $\mathrm{PM}_{2.5}$, respectively.
\end{abstract}

Keywords Korea-United States air quality (KORUS-AQ) · Yellow Sea · Water-soluble ionic species · PM10 · PM2.5 · Methane sulfonic acid (MSA $\cdot \mathrm{CH}_{3} \mathrm{SO}_{3}^{-}$)

\section{Introduction}

Recent economic development in Northeast Asia, especially in China, has resulted in frequent occurrences of high aerosol mass concentration events in the region (Ding and Liu 2014; Wang and Chen 2016). Aerosols originating over land, from natural and/or anthropogenic sources, are deposited into surrounding ocean surfaces, which become the main sources of

Responsible Editor: Soon-Il An.

Joo Wan Cha

jwcha@korea.kr

1 Applied Meteorology Research Division, National Institute of Meteorological Science, Jeju, Republic of Korea

2 Earth system Research Division, National Institute of Meteorological Science, Jeju, Republic of Korea continental aerosols (Arimoto et al. 1996; Zhang et al. 2004). The Gobi Desert and the Loess Plateau areas are key sources of mineral aerosols in Northeast Asia and the North Pacific Ocean (Zhang et al. 1993; Gao et al. 1997). Previous observations of aerosols over coastal seas and at a number of inland sites in Northeast Asia have focused on the spring and early summer seasons (Kim et al. 1998, 2009; Lee et al. 2002; Zhang et al. 2002). Northeast Asia has emerged as the world's largest source of $\mathrm{SO}_{2}$ in recent years ( $\mathrm{Su}$ et al. 2011). Furthermore, it has been reported that by $2020, \mathrm{NO}_{\mathrm{x}}$ emissions in the region may increase five-fold compared to the levels in 1990 (Akimoto 2003). Recent some studies (Gu et al. 2013; Liu et al. 2016) reported the reduction in $\mathrm{NO}_{\mathrm{x}}$ emission trends over China. Although the reduction of $\mathrm{NO}_{\mathrm{x}}$ emission is found over China, the Northeastern Asia is the regions of highest $\mathrm{NO}_{\mathrm{x}}$ concentration in the world (Huang et al. 2017). Emissions from land sources in Northeastern Asia affect the aerosol field over the Yellow Sea, depending 
on atmospheric circulation patterns. Hence, the recent increase in anthropogenic emissions can alter aerosol compositions and their characteristics over the Yellow Sea.

The Korea-United States Air Quality (KORUS-AQ) campaign was an international, multi-organization mission to observe air quality across the Korean peninsula and surrounding waters. KORUS-AQ was conducted by the National Aeronautics and Space Administration (NASA) and their international partners from April to June 2016. National Institute of Meteorological Science (NIMS) of the Korea Meteorological Administration (KMA) measured atmospheric aerosols over the Yellow Sea, which was affected by aerosols originating in various regions of China and Korea during the campaign periods. KORUS-AQ integrated observations from ships, aircrafts, ground sites, and satellites, in conjunction with air quality models, to understand the factors governing air quality across urban, rural, and coastal interfaces in Northeast Asian (https://espo.nasa.gov/home/korus-aq).

Especially, MSA in the marine boundary layer is one of the major end products of the oxidation of dimethyl sulfide (DMS) produced by marine biota. MSA and DMS studies were conducted over the Yellows Sea by Chinese scientists to understand sulfur chemistry in the past (Chen et al. 2012). This study focuses on the $\mathrm{NO}_{3}$ radicals which play an important role as an oxidant in DMS decomposition in the regions of highest $\mathrm{NO}_{\mathrm{x}}$ concentration such as Northeastern Asia (Gao et al. 1996). China emits large amounts of $\mathrm{SO}_{2}$ and $\mathrm{NO}_{\mathrm{x}}$ (Han et al. 2005), which are transported to the Yellow Sea by prevailing westerlies and deposited there to enhance MSA production. For example, Gao et al. (1996) reported an MSA mass concentration of $0.029 \mu \mathrm{g} \mathrm{m}^{-3}$ in TSP (Total Suspended Particle) over the Yellow Sea and East China Sea. Zhang et al. (2015) reported an MSA mass concentration of $0.061 \mu \mathrm{g} \mathrm{m}^{-3}$ in TSP over the Yellow Sea in May 2012. Cha et al. (2016) reported an MSA mass concentration of $0.13 \mu \mathrm{g} \mathrm{m}^{-3}$ in $\mathrm{PM}_{10}$ over the Yellow Sea in April 2015 (Table 1).

This study aims to understand the chemical characteristics of water-soluble aerosols over the Yellow Sea from shipborne sampling data of aerosols acquired during the KORUS-AQ campaign because the Yellow Sea is under the strongest air pollutant influence in the world (Wang and Chen 2016). Water-soluble ions are important constituents of atmospheric aerosols over ocean surfaces. In particular, heavy aerosol events, such as Asian dust and haze over the Yellow Sea, are mainly due to long-range aerosol transport from inland regions, such as China, Korea, and Japan. Therefore, this study focuses on analyzing the concentrations of the major watersoluble ionic compounds and methanesulfonic acid (MSA) in the high aerosol concentration cases observed during the KORUS-AQ campaign. The internal correlations between the chemical ionic species are examined in terms of the chemical species formation in these cases.

\section{Data and Methodology}

The KORUS-AQ campaign involved three cruises conducted using the research vessel Gisang 1, operated by the National Institute of Meteorological Science (NIMS) of the Korea Meteorological Administration (KMA). The first cruise started on May 3, 2016, and ended on May 12, 2016; the second cruise started on May 18, 2016, and ended on May 29, 2016; and the third cruise started on June 5, 2016, and ended on June 13, 2016. The samples obtained during these cruises over the region $35.3-37.3^{\circ} \mathrm{N}$ and 123.2 $125.2^{\circ} \mathrm{E}$ were selected for analysis in this study (Fig. 1).

Five-minute average $\mathrm{PM}_{10}$ (particulate matter less than $10 \mu \mathrm{m}$ in diameter) mass concentrations were measured using a $\mathrm{PM}_{10}$ suspended particulate analyzer ( $\beta$-ray $\mathrm{PM}_{10}$ analyzer, Thermo Scientific Inc., FH62-C14; hereafter, $\beta$-ray $\mathrm{PM}_{10}$ ) on the basis of a $\beta$-ray absorption method. A total of 17 samples were collected using 47-mm Teflon filters and a particle measuring system (APM Inc., PMS-104; hereafter, PMS) equipped with a $\mathrm{PM}_{10}$ and $\mathrm{PM}_{2.5}$ (particulate matter less than $2.5 \mu \mathrm{m}$ in diameter) separator. The study mainly focused on the characteristics of the samples collected through the $\mathrm{PM}_{10}$ and $\mathrm{PM}_{2.5}$ inlets. An aerodynamic particle sizer (TSI Inc., APS-3321; hereafter, APS) was used to observe the aerosol particle size distribution. The measurable concentration range of APS is $0-10,000 \mathrm{~cm}^{-3}$ and the observation range is $0.5-$ $20 \mu \mathrm{m}$ with 52-bin channels. The $\beta$-ray $\mathrm{PM}_{10}$ measures the $\mathrm{PM}_{10}$ mass concentration every $5 \mathrm{~min}$, while the APS measures the size-segregated number concentration every $3 \mathrm{~min}$. The PMS was placed on the deck of the ship at $8 \mathrm{~m}$ above sea level. Samples of $\mathrm{PM}_{10}$ and $\mathrm{PM}_{2.5}$ aerosols were collected for around $10 \mathrm{~h}$ during daytime. That is, the water-soluble ionic mass concentration obtains from PMS for $\mathrm{PM}_{10}$ and $\mathrm{PM}_{2.5}$ and the total $\mathrm{PM}_{10}$ mass concentration does from $\beta$-ray $\mathrm{PM}_{10}$. The size-segregated total PM mass concentration such as $\mathrm{PM}_{10}$ and $\mathrm{PM}_{2.5}$ is from APS.

Meteorological and oceanic parameters, such as temperature, wind direction, wind speed, and sea surface pressure, were observed every 5 min using automatic meteorological instruments installed on the ship. An aerosol observation container was installed on the bow of the ship to protect the instruments from marine hazards as well as to protect the ship from the effects of pollution sources, such as the smokestack. Figure 1 shows the main route of the research vessel over the Yellow Sea during the KORUS-AQ campaign. At the end of each cruise, aerosol samples collected on the filter were analyzed using an ion analyzer (ion chromatograph; hereafter, IC) to measure five types of cations $\left(\mathrm{NH}_{4}^{+}, \mathrm{Na}^{+}, \mathrm{K}^{+}, \mathrm{Ca}^{2+}\right.$, and $\left.\mathrm{Mg}^{2+}\right)$ and five types of anions $\left(\mathrm{SO}_{4}{ }^{2-}, \mathrm{NO}_{3}{ }^{-}, \mathrm{HCOO}^{-}, \mathrm{CH}_{3} \mathrm{COO}^{-}\right.$, and $\left.\mathrm{CH}_{3} \mathrm{SO}_{3}{ }^{-}\right)$. The detection limit and the coefficient of variation of IC vary from 0.29 to $7.48 \mu \mathrm{g} \mathrm{L}^{-1}$ and $0.19 \%$ to $7.33 \%$, respectively, depending on the ion type. 
Table 1 Statistical summary of important water-soluble species in aerosols sampled over the sea around Northeast Asia

\begin{tabular}{|c|c|c|c|c|c|c|c|c|c|c|c|c|}
\hline & MSA & $\mathrm{SO}_{4}{ }^{2-}$ & $\mathrm{NO}_{3}^{-}$ & $\mathrm{Na}^{+}$ & $\mathrm{NH}_{4}^{+}$ & $\mathrm{Mg}^{2+}$ & $\mathrm{Ca}^{2+}$ & nss-SO ${ }_{4}{ }^{2-}$ & nss-K+ & nss- $-\mathrm{Ca}^{2+}$ & Region/ date & $\begin{array}{l}\text { Size- } \\
\text { cut }\end{array}$ \\
\hline Gao et al. (1996) & 0.029 & - & 1.9 & - & - & - & - & 4.0 & - & - & $\begin{array}{l}\text { Yellow Sea, East China Sea/15-25 } \\
\quad \text { May } 1992\end{array}$ & TSP \\
\hline Zhang et al. (2013) & 0.011 & 13.0 & 3.5 & 1.8 & 4.6 & 0.59 & 1.0 & 12.0 & 0.94 & 0.97 & $\begin{array}{l}\text { North Yellow Sea /14-25 } \\
\text { October } 2007\end{array}$ & TSP \\
\hline Zhang et al. (2013) & 0.0081 & 10.0 & 2.9 & 6.0 & 3.1 & 0.89 & 1.0 & 8.6 & 0.62 & 0.81 & $\begin{array}{l}\text { South Yellow Sea /2-24 } \\
\text { November } 2007\end{array}$ & TSP \\
\hline Yang et al. (2015) & 0.0127 & 26.2 & 11.9 & 5.1 & 7.7 & 1.7 & - & 24.9 & 2.58 & - & $\begin{array}{l}\text { Bohai Sea, North Yellow Sea } \\
\text { /21November - } 1 \text { December } 2011\end{array}$ & TSP \\
\hline Zhang et al. (2015) & 0.061 & 8.3 & 8.2 & 1.0 & 2.5 & 0.2 & 0.7 & 8.1 & 0.3 & 0.67 & $\begin{array}{l}\text { Bohai Sea, North -South Yellow Sea / } \\
\text { 2-20 May } 2012\end{array}$ & TSP \\
\hline Zhang et al. (2015) & 0.012 & 6.2 & 6.5 & 2.5 & 2.5 & 0.5 & 1.0 & 5.7 & 0.4 & 0.88 & $\begin{array}{l}\text { Bohai Sea, North -South Yellow Sea } \\
\text { /2-19 November } 2012\end{array}$ & TSP \\
\hline Cha et al. (2016) & 0.13 & 7.5 & 3.0 & 1.33 & 3.2 & 0.2 & 0.4 & 7.2 & 0.2 & 0.3 & $\begin{array}{l}\text { Yellow Sea } / 9-14 \& 24-29 \\
\text { April and } 1-5 \text { May } 2015\end{array}$ & PM10 \\
\hline $\begin{array}{l}\text { Boreddy and } \\
\text { Kawamura } \\
(2015)\end{array}$ & 0.03 & - & 0.84 & 3.3 & 0.23 & 0.42 & - & 2.97 & 0.05 & 0.30 & Western North Pacific sea/Spring & TSP \\
\hline
\end{tabular}

\section{Results and Discussion}

\subsection{Characteristics of Aerosol lonic Species in Total Samples over the Yellow Sea}

The major secondary aerosol mean mass concentrations for nss- $\mathrm{SO}_{4}{ }^{2-}, \mathrm{NO}_{3}{ }^{-}$, and $\mathrm{NH}_{4}{ }^{+}$were $10.195,3.025$, and $3.436 \mu \mathrm{g} \mathrm{m}^{-3}$, respectively, in $\mathrm{PM}_{10}$, and 8.823, 1.021 and $2.966 \mathrm{\mu g} \mathrm{m}^{-3}$, respectively, in $\mathrm{PM}_{2.5}$. Further, the diameters of nss- $\mathrm{SO}_{4}{ }^{2-}$ and $\mathrm{NH}_{4}{ }^{+}$were mostly less than $2.5 \mu \mathrm{m}$; hereafter, size denotes diameter. The diameter of $\mathrm{NO}_{3}{ }^{-}$was mostly greater than $2.5 \mu \mathrm{m}$. Similar values of nss- $\mathrm{SO}_{4}{ }^{2-}, \mathrm{NH}_{4}{ }^{+}$, and $\mathrm{NO}_{3}{ }^{-}$mean mass concentrations in TSP were reported by Zhang et al. (2015) over the Yellow Sea in 2012: 8.6, 3.1, and $2.9 \mathrm{\mu g} \mathrm{m}^{-3}$ for nss- $\mathrm{SO}_{4}{ }^{2-}, \mathrm{NH}_{4}{ }^{+}$, and $\mathrm{NO}_{3}{ }^{-}$, respectively. In this study, these secondary ionic species accounted for $84 \%$ and $89 \%$ of the total analyzed species in $\mathrm{PM}_{10}$ and $\mathrm{PM}_{2.5}$, respectively. This implies that the aerosols collected over the Yellow Sea during the campaign were strongly affected by the anthropogenic emissions over land.

Non-sea salt potassium (nss- $\mathrm{K}^{+}$) is a good indicator of biomass burning (Simoneit 2002), and its diameter is less than $2.5 \mu \mathrm{m}$ (Gaudichet et al. 1995). The nss- $\mathrm{K}^{+}$mass concentration over the Yellow Sea in this study is decreased than that in previous studies (e.g. Zhang et al. 2013; Zhang et al. 2015). The nss-Ca ${ }^{2+}$ from soil (Kang et al. 2003) clearly shows a decreasing trend from land to ocean (Fig. 2). The nss-Ca ${ }^{2+}$ mean mass concentration in this study was $0.4 \mu \mathrm{g} \mathrm{m}^{-3}$ in $\mathrm{PM}_{10}$ and $0.1 \mu \mathrm{g} \mathrm{m}^{-3}$ in $\mathrm{PM}_{2.5}$. The difference between the nss- $\mathrm{Ca}^{2+}$ mean mass concentrations of $\mathrm{PM}_{10}$ and $\mathrm{PM}_{2.5}$ was $0.3 \mu \mathrm{g} \mathrm{m}^{-3}$ on average, and the nss- $\mathrm{Ca}^{2+}$ mean mass concentration of $\mathrm{PM}_{2.5}$ was $0.1 \mu \mathrm{g} \mathrm{m}^{-3}$ on average. Thus, most of the
nss-Ca ${ }^{2+}$ was between 10 and $2.5 \mu \mathrm{m}$ in diameter over the Yellow sea.

The correlation coefficient matrix was employed to analyze the internal relationships among different species. $\mathrm{NH}_{4}{ }^{+}$is strongly correlated with nss- $\mathrm{SO}_{4}{ }^{2-}$ and the correlation coefficients between $\mathrm{NH}_{4}{ }^{+}$and $\mathrm{nss}_{-} \mathrm{SO}_{4}{ }^{2-}$ are 0.84 and 0.97 for $\mathrm{PM}_{10}$ and $\mathrm{PM}_{2.5}$, respectively (Tables 5 and 6). This implies that most of the $\mathrm{NH}_{4}{ }^{+}$was combined with nss- $\mathrm{SO}_{4}{ }^{2-}$. The correlation coefficients between $\mathrm{NO}_{3}{ }^{-}$and $\mathrm{Na}^{+}, \mathrm{Mg}^{2+}$, and nss-Ca ${ }^{2+}$ for $\mathrm{PM}_{10}$ were $0.73,0.74$, and 0.72 , respectively. Thus, $\mathrm{NO}_{3}{ }^{-}$in the $\mathrm{PM}_{10}$ samples existed as compounds of $\mathrm{Na}^{+}, \mathrm{Mg}^{2+}$, and nss-Ca ${ }^{2+}$. These results indicate that the marine and continental sources simultaneously affected the samples during the cruise.

The mean mass concentration of MSA in $\mathrm{PM}_{10}$ and $\mathrm{PM}_{2.5}$ was 0.318 and $0.239 \mu \mathrm{g} \mathrm{m}^{-3}$, respectively. The difference between the MSA mean mass concentrations of $\mathrm{PM}_{10}$ and $\mathrm{PM}_{2.5}$ was $0.079 \mu \mathrm{g} \mathrm{m}^{-3}$ on average and the MSA mean mass concentration of $\mathrm{PM}_{2.5}$ was $0.239 \mu \mathrm{g} \mathrm{m}^{-3}$ on average. Thus, most of the MSA was in $\mathrm{PM}_{2.5}$; the MSA mass concentration in $\mathrm{PM}_{10}$ and $\mathrm{PM}_{2.5}$ ranged from 0.096 to $0.61 \mathrm{\mu g} \mathrm{m}^{-3}$ and from 0.082 to $0.48 \mathrm{\mu g} \mathrm{m}^{-3}$, respectively. In conjunction with the previous measurements (Zhang et al. 2013, 2015; Cha et al. 2016), this study shows an increasing trend of the MSA mass concentration over the Yellow Sea in recent years and the MSA concentration in the central Yellow Sea is larger than that in other regions (see Fig. 2 and Table 1). The increase in MSA within aerosols in the Yellow Sea may be related to the changes in the inputs of the materials, which are related to the formation of MSA from dimethyl sulfide (DMS). High nutrient inputs from the Yellow River and the Yangtze River in China, which 
Fig. 1 Ship track (black line) and target area (red dot-line box) over the Yellow Sea from May 2 to June 13, 2016

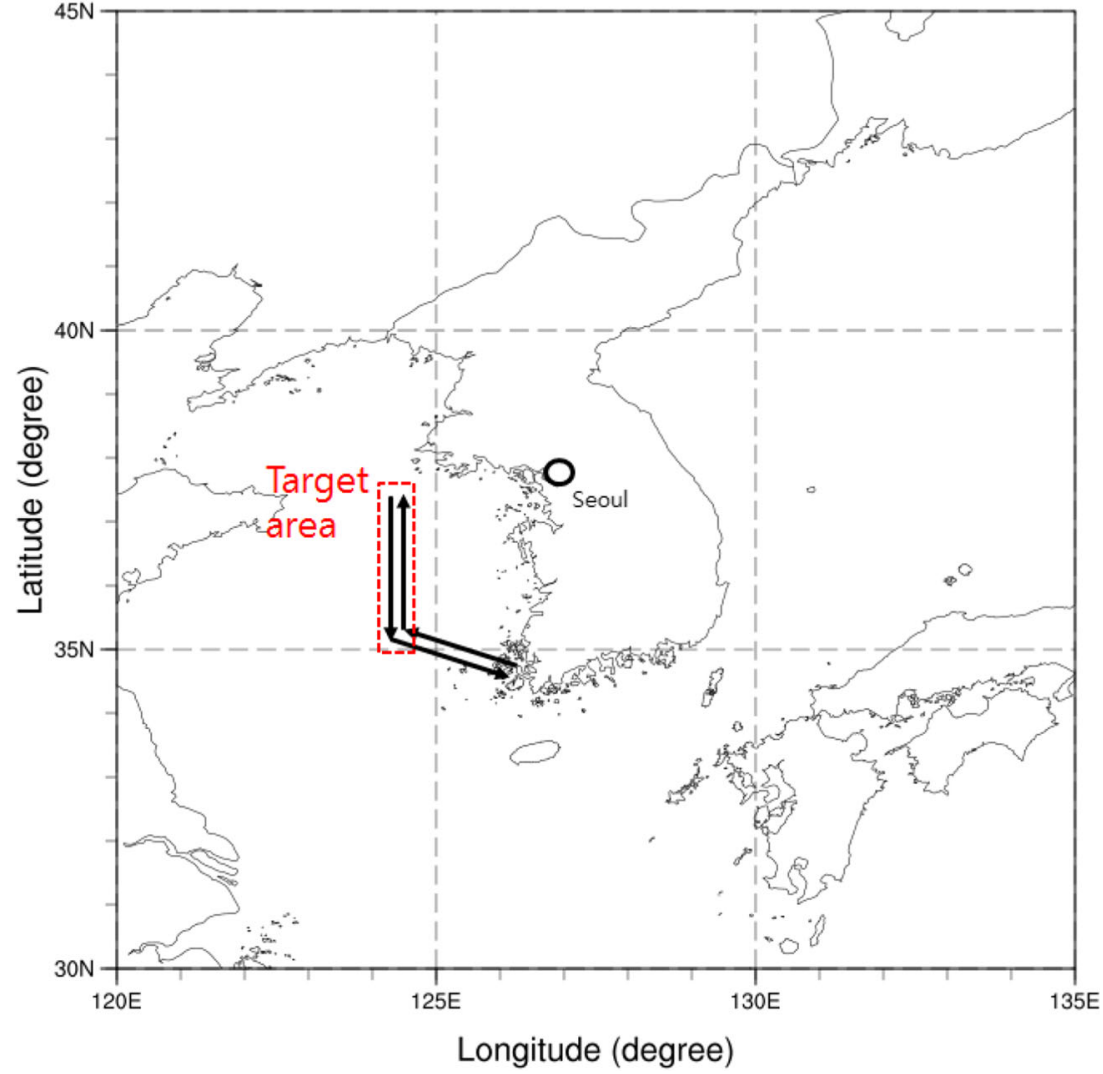

have rapidly increased in recent years (Wei et al. 2015), may have increased the formation of DMS and thus MSA. The deposition of mineral matter transported by air flow from inland deserts to the Yellow Sea (Hsu et al. 2009) can also affect the formation of DMS. The relationship among DMS, MSA, and marine productivity has been observed in many other regions (Calhoun 1992; Ayers et al. 1986; Park et al. 2017). Therefore, this study analyzed the detailed MSA mass concentration even though the MSA was not major watersoluble ions such as for nss- $\mathrm{SO}_{4}{ }^{2-}, \mathrm{NO}_{3}{ }^{-}$, and $\mathrm{NH}_{4}{ }^{+}$.

\subsection{High PM Cases}

\subsubsection{Classification of High PM Cases}

High aerosol mass concentration cases during the experiment were classified using the $\beta$-ray $\mathrm{PM}_{10}$ and APS. The differential mass concentration of a given aerodynamic diameter $\left(\mathrm{dM}_{\text {Dae }}\right)$ for each channel is calculated as

$\mathrm{dM}_{\text {Dae }}=\mathrm{dN}_{\text {Dae }} \frac{\pi}{6} \mathrm{D}_{\mathrm{ve}}^{3} \rho_{\mathrm{p}}$

where $\mathrm{D}_{\mathrm{ae}}$ is the aerodynamic diameter, $\mathrm{dN}_{\mathrm{Dae}}$ is the differential number concentration for a given aerodynamic diameter, $\rho_{\mathrm{p}}$ is the density of the particle $\left(1 \mathrm{~g} \mathrm{~cm}^{-3}\right.$, Katrib et al. 2005), and $\mathrm{D}_{\mathrm{ve}}$ is the volumetric equivalent diameter, all of which were obtained from the APS. $\mathrm{PM}_{10}$ and $\mathrm{PM}_{2.5}$ mass concentrations were calculated from the summation of channels 1-42 and 1-23, respectively. The unit for the differential mass concentration is $\mu \mathrm{g} \mathrm{m}^{-3}$. Seventeen-day data were analyzed after eliminating anchoring periods due to severe weather, fuel supply, and buoy release, as well as obvious contamination from the research vessel.

We performed a mass-frequency distribution analysis for the $\mathrm{PM}_{10}$ hourly series measured on the ship and in Seoul during the study period (Fig. 3 ). The average $\mathrm{PM}_{10}$ mass concentrations over the Yellow Sea and in Seoul during the study period were around 40 and $48 \mu \mathrm{g} \mathrm{m}^{-3}$, respectively. The measurements at the two sites were similar despite differences in the station type: the ship (Gisang 1) is a background station located on the sea, whereas Seoul is a megacity affected by many types of aerosol sources. The peak aerosol mass concentration was $30-40 \mathrm{\mu g} \mathrm{m}^{-3}$ on the ship and $40-50 \mathrm{\mu g} \mathrm{m}^{-3}$ at the Seoul station, and the frequency above $50 \mu \mathrm{g} \mathrm{m}^{-3}$ at Seoul was higher than that on the ship. Further, the frequency above $100 \mathrm{mg} \mathrm{m}^{-3}$ was higher than the frequency for the range 70 $100 \mu \mathrm{g} \mathrm{m}^{-3}$ both on the ship and at Seoul station. It shows that both sites have similar frequency of mass concentration distribution. The cases above $100 \mu \mathrm{g} \mathrm{m}^{-3}$ during the campaign was from same high mass concentration episodes (the Asian dust and haze cases) at both site (not shown). That is, longrange aerosol transport from Chinese sources. 


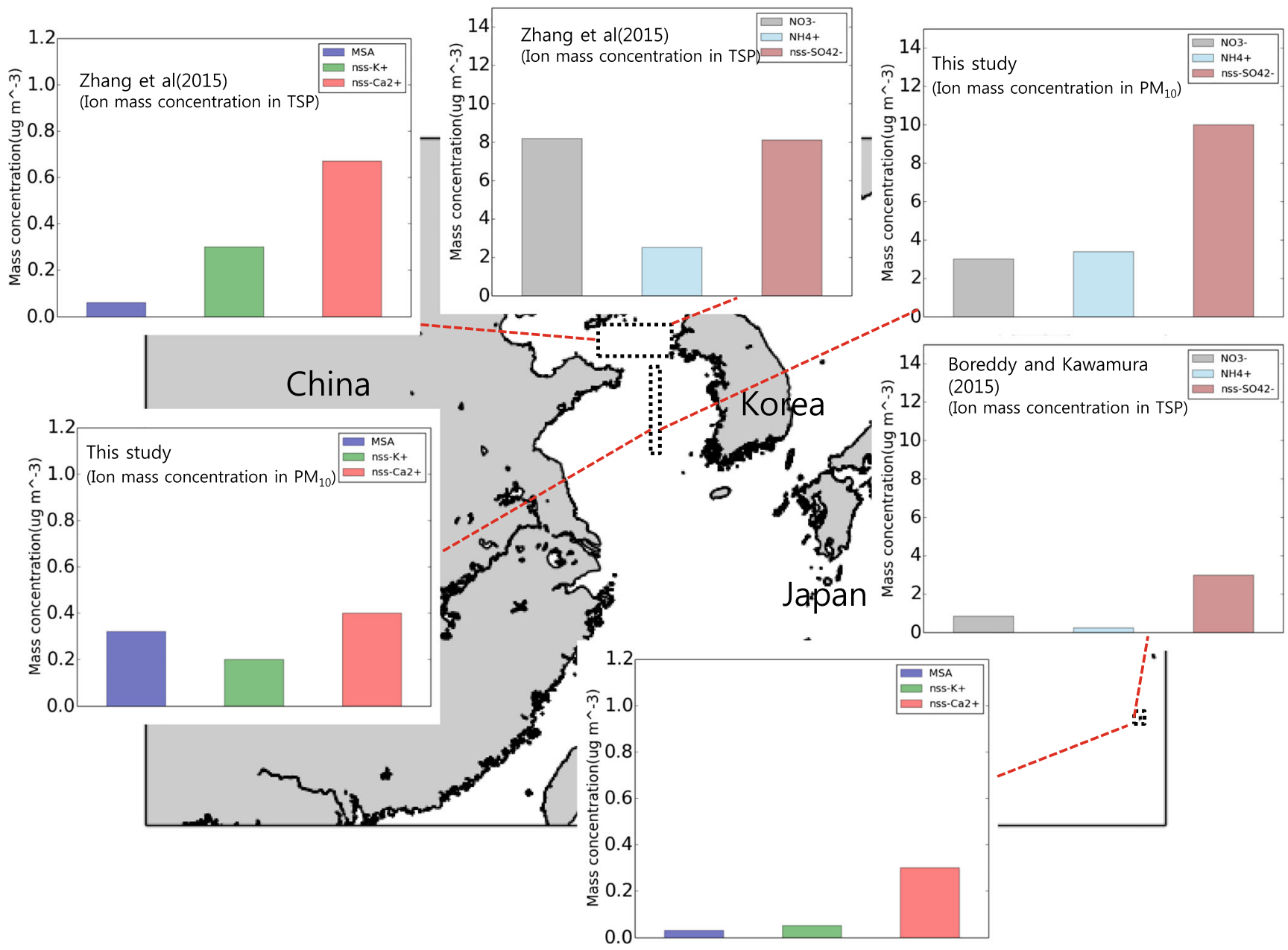

Fig. 2 Comparison between the observed ranges for water-soluble ionic mass concentrations using PMS in this study and those in previous studies over the sea near Northeast Asia

Classification of the dust and haze events over the Yellow Sea in this study follows the work of Cho et al. (2013): for "Asian dust" ("haze"), the hourly-mean $\mathrm{PM}_{2.5} / \mathrm{PM}_{10}$ ratio was below $40 \%$ (above $80 \%$ ). Figure 4 shows the method for the classification of Asian dust and haze event by flowchart. Figure 5a shows the $\mathrm{PM}_{10}$ mass concentration from the $\beta$ ray $\mathrm{PM}_{10}$, and Fig. $5 \mathrm{~b}$ shows the ratios of $\mathrm{PM}_{2.5} / \mathrm{PM}_{10}$ over the Yellow Sea. In Fig. 5b, the blue (red) regions indicate ratios below (above) 80\% (40\%). The dust and haze events were selected when the $\mathrm{PM}_{10}$ concentration exceeded $50 \mu \mathrm{g} \mathrm{m}^{-3}$, i.e., the value corresponding to the sum of the mean and one standard deviation of the $\mathrm{PM}_{10}$ mass concentration over the Yellow Sea. On the basis of this criterion, one Asian dust event (Case I: May 7, 2016) and three haze events (Case II: May 12, 2016; Case III: May 21, 2016; and Case IV: May 29, 2016)) were identified (Table 2). The aerosol chemical compositions were sampled in Cases I, II, and III for $\mathrm{PM}_{10}$, and in Cases I, II, and IV for $\mathrm{PM}_{2.5}$. The cases were selected if more than $50 \mathrm{\mu g} \mathrm{m}^{-3}$ was measured at least once using the $\beta$-ray $\mathrm{PM}_{10}$. The cumulative $\mathrm{PM}_{10}$ mass concentrations collected using 47-mm Teflon filters using PMS during each case day were 73,47 , and $52 \mu \mathrm{g} \mathrm{m}^{-3}$ in Cases I, II, and III, respectively, and the $\mathrm{PM}_{2.5}$ mass concentrations were 22, 30, and $52 \mu \mathrm{g} \mathrm{m}^{-3}$ in Cases I, II, and IV, respectively. The aerosol chemical compositions were not sampled in Case IV for $\mathrm{PM}_{10}$ and Case III for $\mathrm{PM}_{2.5}$ during the cruise.

\subsubsection{Origins of High PM Cases}

The HYSPLIT 4 model developed at the National Oceanic and Atmospheric Administration/Air Resources Laboratory was used to estimate the upstream path of air flow over the Yellow Sea during the KORUS-AQ campaign. The HYSPLIT simulations were run using the Unified Model-Global Data Assimilation and Prediction System (UM-GDAPS) weather data from KMA for $72 \mathrm{~h}$ prior to each case, at $500 \mathrm{~m}$ above the center of the vessel observation route $\left(36.16^{\circ} \mathrm{N}, 124.29^{\circ} \mathrm{E}\right)$.

Figure 6 shows the 72-h backward trajectories for the selected high $\mathrm{PM}_{10}$ mass concentration cases from the HYSPLIT simulations. In Case I (Asian dust case; hereafter, $\mathrm{AD}$ ), air from the Inner Mongolia region passed through the main source regions of Asian dust to affect the sampling 


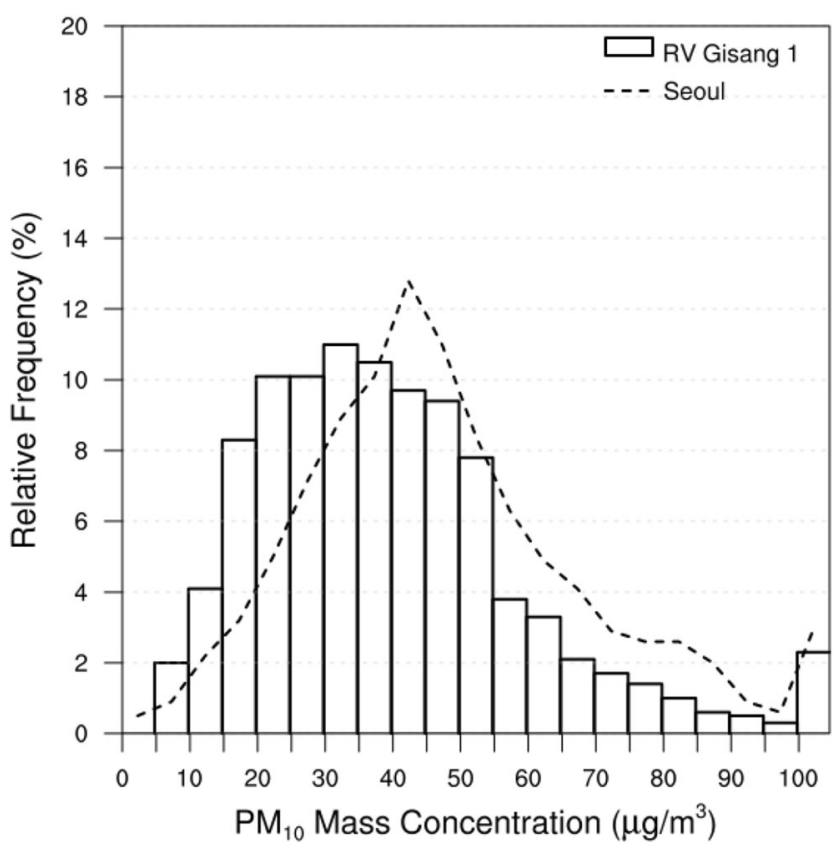

Fig. 3 Histogram of $\mathrm{PM}_{10}$ mass concentration by $\mathrm{PM}_{10}$ analyzer ( $\beta$-ray application) in research vessel Gisang 1 (square box) and Seoul (dashed line) from May 2 to June 13, 2016

region. In Case II, i.e., the haze and mist from Northeast China (HMNC) case, air from Liaoning province in Western Manchuria stayed over the Yellow Sea for extended periods after leaving the land. The classification criterion of mist and haze is $75 \%$ RH: Mist $\geq 75 \%$ RH and Haze $<75 \%$ RH (http:// www.kma.go.kr). In Case III, i.e., the haze from the Korean Peninsula (HKP) case, air pollutants from South Korea affected the sampling area. In Case IV, i.e., the haze from the Shandong Peninsula in China (HSPC) case, air flows originating in inland China passed through the Shandong Peninsula, an area of recent rapid industrialization, and stayed over the Yellow Sea for extended periods before arriving at the sampling site. Table 2 provides detailed information on the observations for the four cases.

\subsubsection{Characteristics of Aerosol Ionic Species in High PM Cases}

The mass concentration of nss- $\mathrm{SO}_{4}{ }^{2-}$ is larger than that of the other ions, even though $\mathrm{PM}_{10}$ and $\mathrm{PM}_{2.5}$ were not sampled in HSPC and HKP, respectively (Fig. 7). The mass concentration varies in the order HSPC $>$ HMNC $>$ HKP $>$ AD. Thus, most of the nss- $\mathrm{SO}_{4}{ }^{2-}$ over the Yellow Sea in May 2016 came from the Shandong Peninsula and Northeast China. The $\mathrm{NH}_{4}{ }^{+}$mass concentration varies nearly identically to that of nss- $\mathrm{SO}_{4}{ }^{2-}$, except for the differences in the mass concentrations. This suggests that the $\mathrm{NH}_{4}{ }^{+}$over the Yellow Sea came from nearly the same sources as nss- $\mathrm{SO}_{4}{ }^{2-}$, mainly as nss- $\mathrm{SO}_{4}{ }^{2-}$ compounds in $\mathrm{PM}_{2.5}$. Figure 7 also suggests that the nss- $\mathrm{SO}_{4}{ }^{2-}$ and $\mathrm{NH}_{4}{ }^{+}$over the Yellow Sea were affected by sources in South Korea, although China is the main source of these two ions. The mass concentration of $\mathrm{NO}_{3}{ }^{-}$varies in the order HSPC $>$ AD $>$ HKP $>$ HMNC. For the four cases, $\mathrm{NO}_{3}{ }^{-}$, $\mathrm{Na}^{+}, \mathrm{Mg}^{2+}$, and nss-Ca ${ }^{2+}$ were mostly contained in $\mathrm{PM}_{10}$. These results suggest that $\mathrm{NO}_{3}{ }^{-}$is mostly combined with $\mathrm{Na}^{+}, \mathrm{Mg}^{2+}$, and nss- $\mathrm{Ca}^{2+}$ in $\mathrm{PM}_{10}$ during high aerosol mass concentration events over the Yellow Sea. This implies that
Fig. 4 Flowchart for classification of Asian dust and haze using $\mathrm{PM}_{10}$ mass concentration by $\mathrm{PM}_{10}$ analyzer ( $\beta$-ray application) and the ratio of $\mathrm{PM}_{2.5} / \mathrm{PM}_{10}$ by APS in research vessel Gisang 1

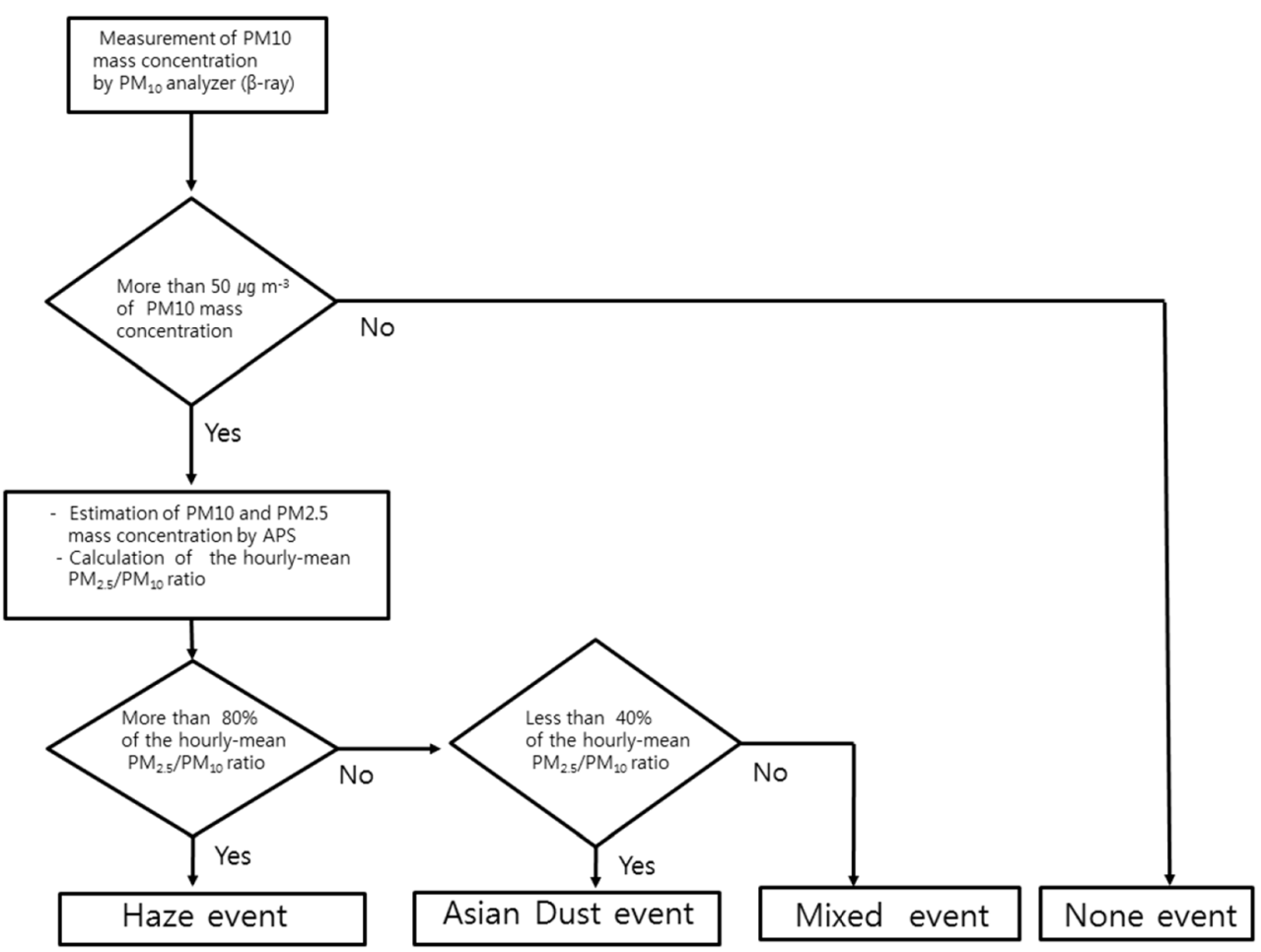


Fig. 5 a $\mathrm{PM}_{10}$ mass concentration by $\mathrm{PM}_{10}$ analyzer ( $\beta$-ray) and $\mathbf{b}$ classification of Asian dust and haze by the ratio of $\mathrm{PM}_{2.5} / \mathrm{PM}_{10}$ by APS over the Yellow Sea from May 2 to June 13, 2016
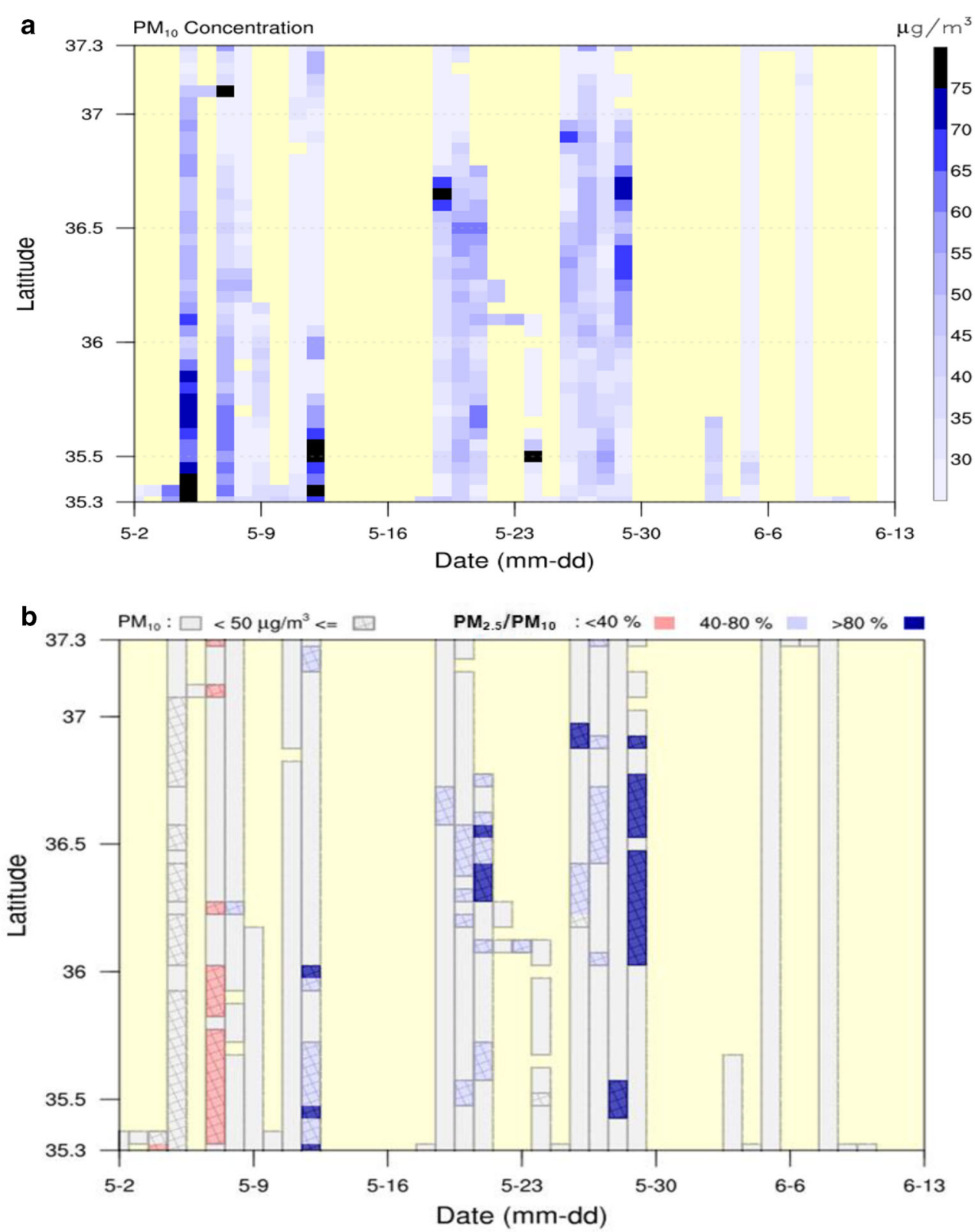

ions such as $\mathrm{Mg}^{2+}$ and nss-Ca ${ }^{2+}$ in $\mathrm{PM}_{10}$ among dust particles during $\mathrm{AD}$ reacted more with nitrates than with sulfates from anthropogenic sources in China. The nss- $\mathrm{K}^{+}$from biomass burning and combustion were mostly in $\mathrm{PM}_{2.5}$ with the largest

Table 2 Aerosol sampling information using PMS for the four high aerosol mass concentration cases over the Yellow Sea during KORUS-AQ 2016

\begin{tabular}{|c|c|c|c|c|c|c|c|}
\hline \multirow[t]{2}{*}{ Case } & \multicolumn{2}{|l|}{ LST } & \multicolumn{2}{|l|}{ Area } & \multicolumn{2}{|c|}{ No. of Samples } & \multirow[t]{2}{*}{ Remark } \\
\hline & Start Time & End Time & Longitude $(\mathrm{N})$ & Latitude (E) & $\mathrm{PM}_{10}$ & $\mathrm{PM}_{2.5}$ & \\
\hline Case I & 2016-05-07 09:00 & 2016-05-07 18:13 & $37.31 \rightarrow 35.33$ & $124.28 \rightarrow 124.28$ & 1 & 1 & Asian Dust \\
\hline Case II & 2016-05-12 08:00 & $2016-05-12$ 17:55 & $37.33 \rightarrow 35.35$ & $124.28 \rightarrow 124.28$ & 1 & 1 & Haze \& Mist \\
\hline Case III & 2016-05-21 07:59 & 2016-05-21 20:02 & $35.34 \rightarrow 36.27$ & $124.28 \rightarrow 125.75$ & 1 & - & Haze \\
\hline Case IV & 2016-05-29 08:01 & $2016-05-29$ 16:24 & $37.32 \rightarrow 35.32$ & $124.28 \rightarrow 124.32$ & - & 1 & Haze \\
\hline
\end{tabular}



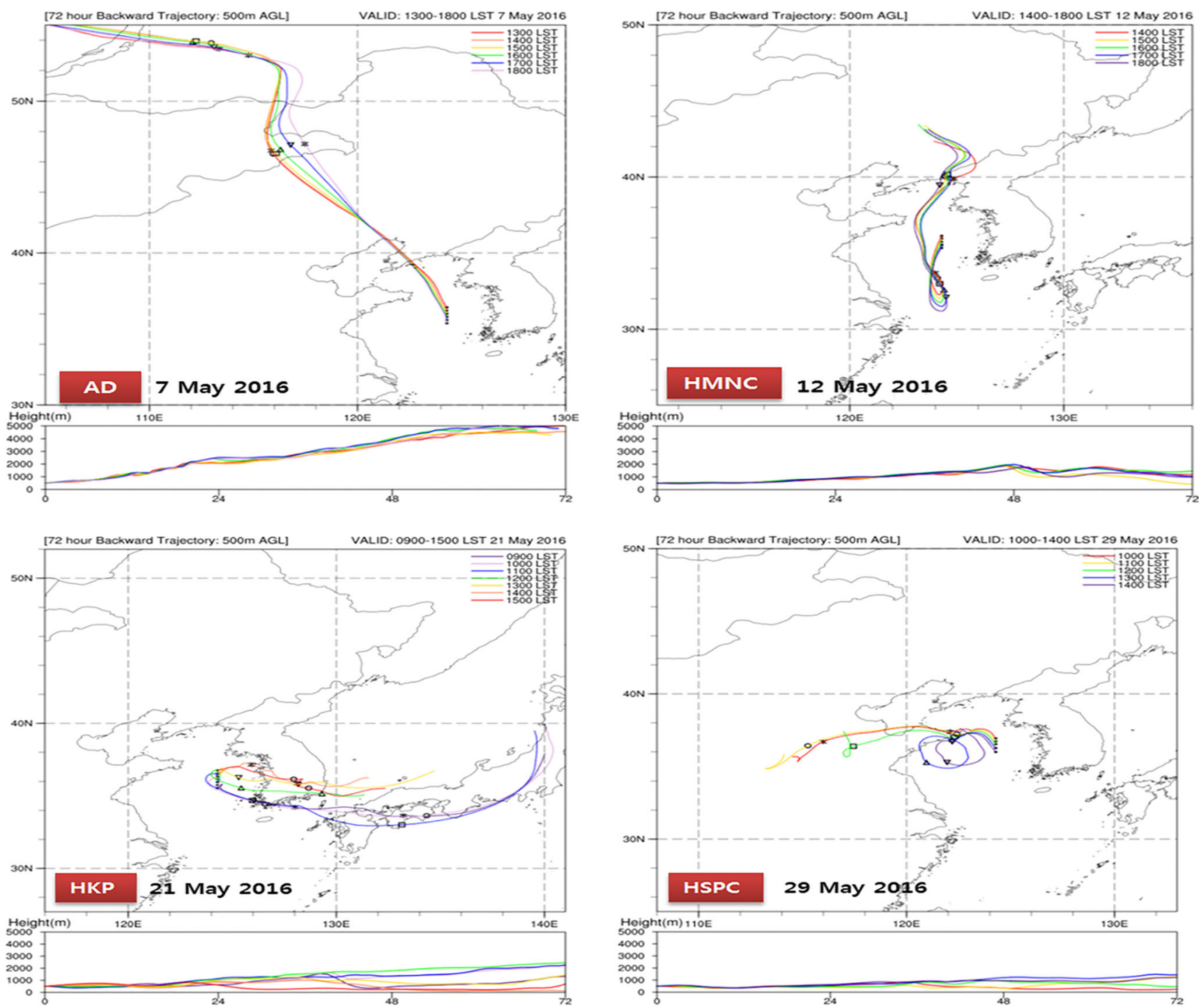

Fig. 6 Backward trajectories for high concentration cases from May 2 to June 13, 2016 (AD: Asian dust case; HMNC: haze and mist from Northeast China case; HKP: haze from the Korean Peninsula case; HSPC: haze from the Shandong Peninsula in China case)

mass concentration in HSPC (see Fig. 7 and Table 3). These results show that during the campaign, the Shandong Peninsula (HSPC) was the largest anthropogenic source of the ions over the Yellow Sea.

To identify the main sources of the sampled water-soluble ions, we calculated the Enrichment factor (EF) in aerosols using their contents in seawater and the soil crust. In this method, $\mathrm{Na}^{+}$ and nss- $\mathrm{Ca}^{2+}$ are regarded as conservative elements of the marine and crustal sources (Nishikawa et al. 1991; Millero 2006). The EFs of an ion $\mathrm{X}$ are defined as follows:

$\mathrm{EF}_{\text {seawater }}=\left(\mathrm{X} / \mathrm{Na}^{+}\right)_{\text {aerosol }} /\left(\mathrm{X} / \mathrm{Na}^{+}\right)_{\text {seawater }}$

and

$\mathrm{EF}_{\text {crust }}=\left(\mathrm{X} / \mathrm{nss}^{-} \mathrm{Ca}^{2+}\right)_{\text {aerosol }} /\left(\mathrm{X} / \mathrm{nss}^{-} \mathrm{Ca}^{2+}\right)_{\text {crust }}$

where the subscript "aerosol" denotes the mass concentration ratio between $\mathrm{X}$ and $\mathrm{Na}^{+}$or nss-Ca ${ }^{2+}$ in the aerosol samples. The subscripts "seawater" and "crust" denote the ratio of X to $\mathrm{Na}^{+}$in seawater and $\mathrm{X}$ to nss-Ca ${ }^{2+}$ in the crust, respectively. The $\mathrm{Na}^{+}$and nss- $-\mathrm{Ca}^{2+}$ mass concentrations for seawater and crust obtain from Nishikawa et al. (1991).

The EFs of the secondary ions (nss- $\mathrm{SO}_{4}{ }^{2-}, \mathrm{NO}_{3}{ }^{-}$, and $\mathrm{NH}_{4}{ }^{+}$) for crustal sources are high in all the four cases (Table 4), implying that these ions are not from crustal sources. The EF of $\mathrm{NO}_{3}{ }^{-}$in $\mathrm{PM}_{2.5}$ in $\mathrm{HMNC}$ for crustal sources is smaller than the EFs of nss- $\mathrm{SO}_{4}{ }^{2-}$ and $\mathrm{NH}_{4}{ }^{+}$, suggesting that the $\mathrm{NO}_{3}{ }^{-}$in $\mathrm{HMNC}$ is more affected by crustal sources compared to nss- $\mathrm{SO}_{4}{ }^{2-}$ and $\mathrm{NH}_{4}{ }^{+}$. The EFs of nss$\mathrm{SO}_{4}{ }^{2-}$ for seawater source ranged from 13 in $\mathrm{PM}_{10}$ in $\mathrm{AD}$ to 83 in $\mathrm{PM}_{2.5}$ in HSPC. This implies that nss- $\mathrm{SO}_{4}{ }^{2-}$ is from nonsea salt sources. The nss- $\mathrm{SO}_{4}{ }^{2-}$ in $\mathrm{AD}$ is smaller than those in the haze cases (HMNC, HKP, and HSPC), suggesting that aerosols over the Yellow Sea in $\mathrm{AD}$ are affected more by the 
Fig. 7 Major chemical ionic species in $\mathbf{a} \mathrm{PM}_{10}$ and $\mathbf{b} \mathrm{PM}_{2.5}$ using PMS for high aerosol mass concentration cases over the Yellow Sea during the KORUSAQ campaign, 2016
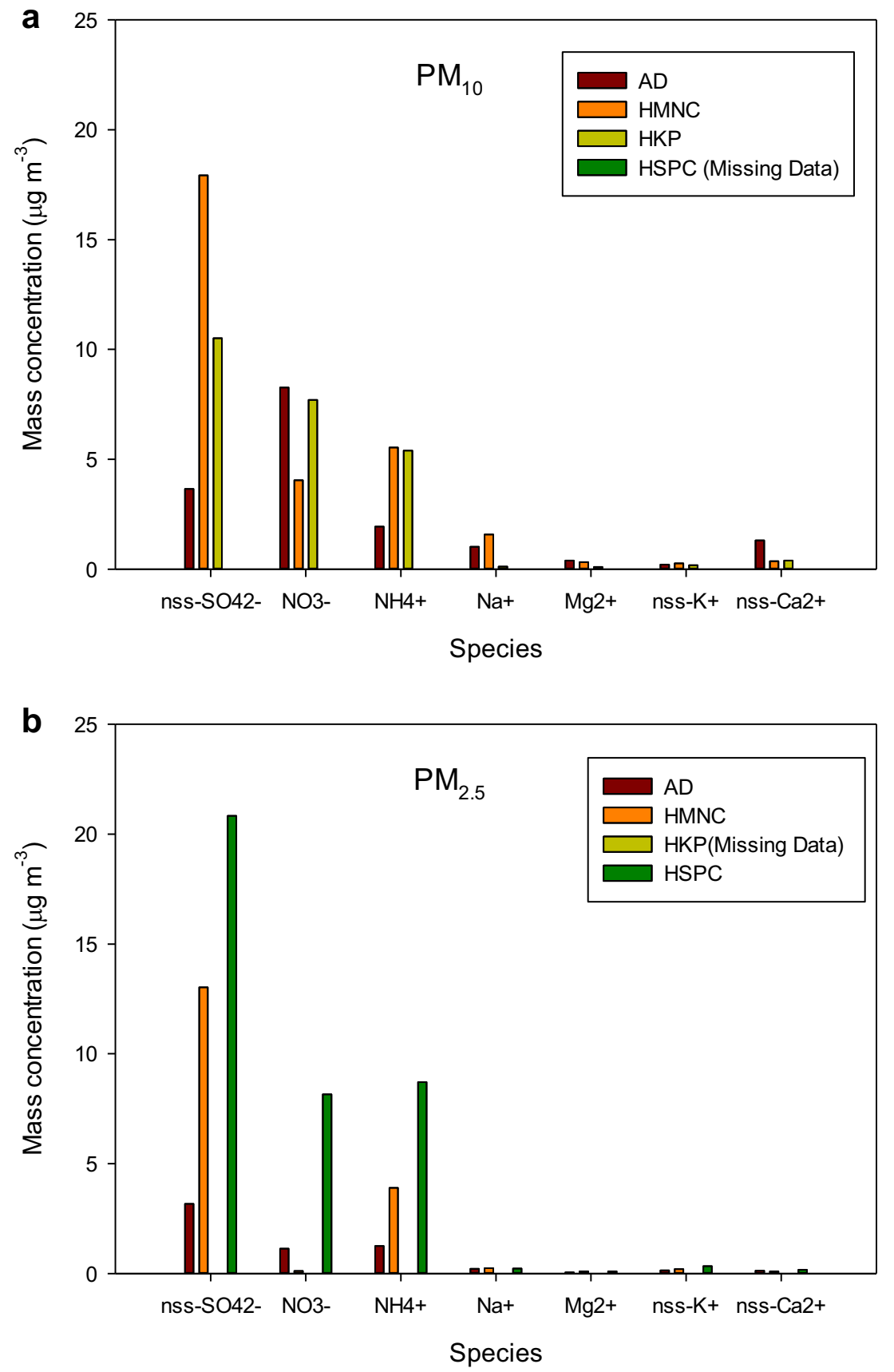

sulfates from seawater than in the other three cases. The EF of $\mathrm{K}^{+}$and $\mathrm{nss}-\mathrm{Ca}^{2+}$ in the four cases varies as follows: 5.1-10.0 (4.2-9.5) for $\mathrm{K}^{+}$in $\mathrm{PM}_{10}\left(\mathrm{PM}_{2.5}\right)$ and 10.0-33.8 (2.8-4.5) for nss- $\mathrm{Ca}^{2+}$ in $\mathrm{PM}_{10}\left(\mathrm{PM}_{2.5}\right)$. The EF of $\mathrm{K}^{+}$for crustal source lies in the range of $0.3-0.5(0.2-0.5)$ in $\mathrm{PM}_{10}\left(\mathrm{PM}_{2.5}\right)$, indicating that for the four cases, the $\mathrm{K}^{+}$and nss- $\mathrm{Ca}^{2+}$ in the samples are mostly from the crustal source.

In recent years, Northeast Asia has emitted large amounts of $\mathrm{SO}_{2}$ and $\mathrm{NO}_{\mathrm{x}}$ (Han et al. 2005). The oxidation of $\mathrm{SO}_{2}$ and $\mathrm{NO}_{\mathrm{x}}$ can contribute to high levels of secondary ions, such as $\mathrm{SO}_{4}{ }^{2-}$ and $\mathrm{NO}_{3}{ }^{-} \cdot \mathrm{NH}_{3}$ from agricultural activity and livestock farming (Galloway et al. 1996) and mineral dust transported from desert areas are rich in $\mathrm{Ca}^{2+}$ ions, and they play an important role in neutralizing acid aerosols. To understand the relationship between the cations $\left(\mathrm{NH}_{4}{ }^{+}\right.$and $\left.\mathrm{nss}-\mathrm{Ca}^{2+}\right)$ and the anions (nss- $\mathrm{SO}_{4}{ }^{2-}$ and $\mathrm{NO}_{3}{ }^{-}$), these two groups of ionic species were converted to equivalent concentrations for comparison. Figure 8 shows the correlation between the sum of the acidic ionic species (nss- $\mathrm{SO}_{4}{ }^{2-}$ and $\mathrm{NO}_{3}{ }^{-}$) and the sum of the alkaline ionic species $\left(\mathrm{NH}_{4}{ }^{+}\right.$and $\left.\mathrm{Ca}^{2+}\right)$ in the form of equivalent concentration, in aerosols sampled over the Yellow Sea. These two groups are strongly correlated, with a slope of 1.2 
Table 3 Comparison the mass concentrations of water-soluble species in aerosols sampled using PMS in High PM cases and in total period of the campaign over the Yellows sea

\begin{tabular}{|c|c|c|c|c|c|c|c|c|c|c|c|}
\hline & MSA & $\mathrm{SO}_{4}^{2-}$ & $\mathrm{NO}_{3}^{-}$ & $\mathrm{Na}^{+}$ & $\mathrm{NH}_{4}^{+}$ & $\mathrm{Mg}^{2+}$ & $\mathrm{Ca}^{2+}$ & nss- $\mathrm{SO}_{4}{ }^{2-}$ & nss- K+ & nss- $\mathrm{Ca}^{2+}$ & Size-cut \\
\hline \multirow[t]{2}{*}{ Asian Dust cases (AD, Case I) } & 0.212 & 3.906 & 8.268 & 1.022 & 1.937 & 0.389 & 1.352 & 3.650 & 0.208 & 1.312 & PM10 \\
\hline & 0.197 & 3.226 & 1.134 & 0.214 & 1.250 & 0.055 & 0.142 & 3.172 & 0.145 & 0.134 & PM2.5 \\
\hline \multirow[t]{2}{*}{ Haze \& Mist case (HMNC, Case II } & 0.609 & 18.326 & 4.044 & 1.579 & 5.536 & 0.32 & 0.426 & 17.929 & 0.266 & 0.366 & PM10 \\
\hline & 0.477 & 13.088 & 0.119 & 0.243 & 3.900 & 0.103 & 0.113 & 13.027 & 0.200 & 0.104 & PM2.5 \\
\hline \multirow[t]{2}{*}{ Haze case (HKP, Case III) } & 0.614 & 10.541 & 7.705 & 0.115 & 5.393 & 0.105 & 0.399 & 10.512 & 0.179 & 0.395 & PM10 \\
\hline & - & - & - & - & - & - & - & - & - & - & PM2.5 \\
\hline \multirow[t]{2}{*}{ Haze Case (HSPC, Case IV) } & - & - & - & - & - & - & - & - & - & - & PM10 \\
\hline & 0.173 & 20.891 & 8.151 & 0.230 & 8.714 & 0.100 & 0.178 & 20.833 & 0.344 & 0.170 & PM2.5 \\
\hline \multirow[t]{2}{*}{ Average of total samples } & 0.319 & 10.195 & 3.025 & 0.659 & 3.436 & 0.244 & 0.475 & 10.029 & 0.229 & 0.450 & PM10 \\
\hline & 0.239 & 8.823 & 1.021 & 0.145 & 2.966 & 0.077 & 0.137 & 8.787 & 0.214 & 0.188 & PM2.5 \\
\hline
\end{tabular}

for $\mathrm{PM}_{10}$ and 1.1 for $\mathrm{PM}_{2.5}$. This finding is similar to that of Zhang et al. (2013) over the Yellow Sea. This implies that most of the acidic ionic species were neutralized by the alkaline species over the Yellow Sea. Thus, nss- $\mathrm{SO}_{4}{ }^{2-}$ and $\mathrm{NO}_{3}{ }^{-}$ from anthropogenic $\mathrm{SO}_{2}$ and $\mathrm{NO}_{\mathrm{x}}$ are adsorbed onto wet sand aerosol particles, and are then combined with $\mathrm{Ca}^{2+}$ by replacing $\mathrm{CO}_{3}{ }^{2-}$ in $\mathrm{CaCO}_{3}$ from crustal sources during the longrange transport (Zhang et al. 2013). In this study, nss-Ca ${ }^{2+}$ showed a good correlation with $\mathrm{NO}_{3}{ }^{-}$(Tables 5 and 6). Thus, the reaction processes of $\mathrm{Ca}^{2+}$ play significant roles in reducing acidic aerosols over the Yellow Sea.

$\mathrm{NH}_{4}{ }^{+}$has a strong correlation with nss- $\mathrm{SO}_{4}{ }^{2-}$ and $\mathrm{NO}_{3}{ }^{-}$ (Tables 5 and 6). This study applied the method of RogulaKozłowska et al. (2014) for estimating $\left(\mathrm{NH}_{4}\right)_{2} \mathrm{SO}_{4}$ and $\mathbf{N H}_{4} \mathbf{N O}_{3}$. Figure 9 shows the estimated $\left(\mathrm{NH}_{4}\right)_{2} \mathrm{SO}_{4}$ and $\mathrm{NH}_{4} \mathrm{NO}_{3}$. Most of the $\left(\mathrm{NH}_{4}\right)_{2} \mathrm{SO}_{4}$ is in $\mathrm{PM}_{2.5}$, and the mass concentration in HSPC is extremely high. The mass concentration of $\left(\mathrm{NH}_{4}\right)_{2} \mathrm{SO}_{4}$ varies in the order HSPC > $\mathrm{HMNC}>\mathrm{HKP}>\mathrm{AD}$ (Fig. 9), i.e., in the high aerosol mass concentration cases during the campaign, most of the $\left(\mathrm{NH}_{4}\right)_{2} \mathrm{SO}_{4}$ was from China. $\mathrm{NH}_{4} \mathrm{NO}_{3}$ does not appear in HMNC, and HKP shows large amounts of $\mathrm{NH}_{4} \mathrm{NO}_{3}$, indicating that the amount of $\mathrm{NH}_{4} \mathrm{NO}_{3}$ is substantially reduced, while air flows travel over the sea surface for long periods after leaving the land, and vice versa.

The $\mathrm{NO}_{3}{ }^{-}$to nss- $\mathrm{SO}_{4}{ }^{2-}$ ratio in aerosols can be used to track the relative contribution of stationary and mobile sources to the secondary aerosols (Park and Lim 2006). Ko et al. (2017) estimated a ratio of $0.01-13.72$ for $\mathrm{PM}_{10}$ and 0.00 0.92 for $\mathrm{PM}_{2.5}$ over the Yellow Sea. The ratios were 2.27, 0.23 , and 0.73 for $\mathrm{PM}_{10}$ in $\mathrm{AD}, \mathrm{HMNC}$, and HKP, respectively, and $0.36,0.009$, and 0.39 for $\mathrm{PM}_{2.5}$ in $\mathrm{AD}, \mathrm{HNMC}$, and HSPC, respectively. The contributions from stationary sources are high for HMNC. Mobile (stationary) sources had a greater

Table 4 Enrichment factors for high aerosol mass concentration cases over the Yellow Sea during KORUS-AQ 2016

\begin{tabular}{|c|c|c|c|c|c|c|c|c|c|c|c|c|c|c|c|c|}
\hline & \multicolumn{8}{|l|}{$\mathrm{PM}_{10}$} & \multicolumn{8}{|l|}{$\mathrm{PM}_{2.5}$} \\
\hline & \multicolumn{4}{|l|}{ Crust } & \multicolumn{4}{|c|}{ Seawater } & \multicolumn{4}{|l|}{ Crust } & \multicolumn{4}{|c|}{ Seawater } \\
\hline & $\mathrm{AD}$ & HMNC & HKP & HSPC & $\mathrm{AD}$ & HMNC & HKP & HSPC & $\mathrm{AD}$ & HMNC & HKP & HSPC & $\mathrm{AD}$ & HMNC & HKP & HSPC \\
\hline nss- $\mathrm{SO}_{4}{ }^{2-}$ & 912 & 4482 & 2628 & N/A & 14 & 72 & 42 & N/A & 793 & 3257 & N/A & 5208 & 13 & 52 & NA & 83 \\
\hline $\mathrm{NO}_{3}^{-}$ & 2067 & 1011 & 1348 & N/A & - & - & - & - & 283 & 30 & N/A & 5208 & - & - & - & - \\
\hline $\mathrm{NH}_{4}^{+}$ & 484 & 1384 & 1348 & N/A & - & - & - & - & 312 & 974 & N/A & 2178 & - & - & - & - \\
\hline $\mathrm{Na}^{+}$ & 1.3 & 2.1 & 0.15 & N/A & 1.0 & 1.0 & 1.0 & N/A & 0.3 & 0.3 & N/A & 0.3 & 1.0 & 1.0 & N/A & 1.0 \\
\hline $\mathrm{Mg}^{2+}$ & 1.2 & 1.0 & 0.3 & N/A & 3.2 & 2.7 & 0.9 & N/A & 0.2 & 0.3 & N/A & 0.3 & 0.5 & 0.9 & N/A & 0.8 \\
\hline $\mathrm{K}^{+}$ & 0.4 & 0.5 & 0.3 & N/A & 6.8 & 10.0 & 5.1 & N/A & 0.2 & 0.3 & N/A & 0.5 & 4.2 & 5,8 & N/A & 9.5 \\
\hline nss-Ca ${ }^{2+}$ & 1.0 & 1.0 & 1,0 & N/A & 33.8 & 10.6 & 10.0 & N/A & 1.0 & 1.0 & N/A & 1.0 & 3.6 & 2.8 & N/A & 4.5 \\
\hline
\end{tabular}

N/A, Missing data, -, Not calculated 


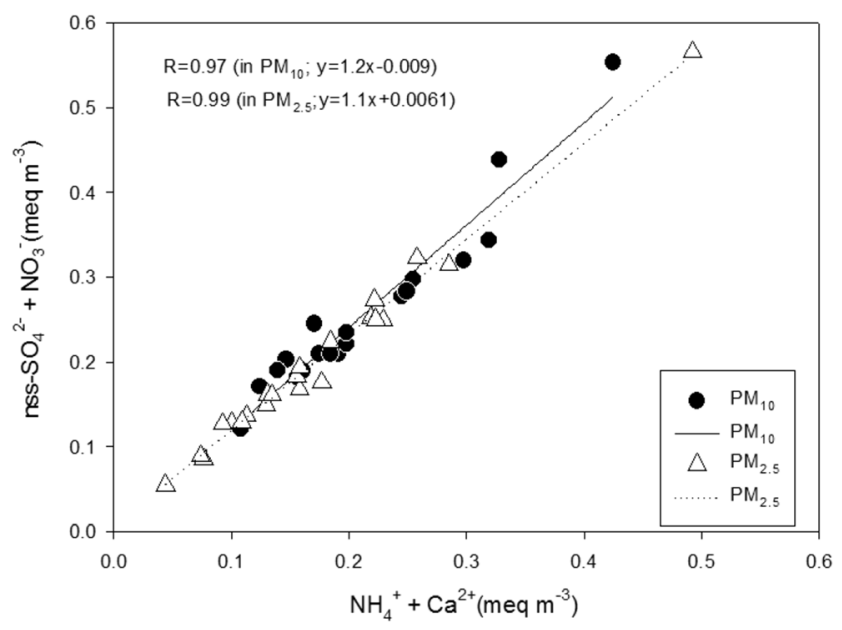

Fig. 8 Correlation between the sum of acidic ions (nss- $\mathrm{SO}_{4}{ }^{2-}$ and $\mathrm{NO}_{3}{ }^{-}$) and the sum of alkaline ions $\left(\mathrm{NH}_{4}{ }^{+}\right.$and $\left.\mathrm{Ca}^{2+}\right)$, in the form of equivalent concentration in aerosols sampled using PMS over the Yellow Sea during the KORUS-AQ campaign, 2016

effect on the $\mathrm{PM}_{10}\left(\mathrm{PM}_{2.5}\right)$ in $\mathrm{AD}$. These results show that during the campaign, stationary sources mostly contributed to high aerosol mass cases, and mobile sources affected $\mathrm{PM}_{10}$ more than $\mathrm{PM}_{2.5}$ over the Yellow Sea.

\subsubsection{MSA and Contribution of Biogenic $\mathrm{SO}_{4}{ }^{2-}$ in High PM Cases}

MSA in the marine boundary layer is one of the major end products of the oxidation of dimethyl sulfide (DMS) produced by marine biota. The formation of MSA from DMS oxidation is affected by the concentrations of $\mathrm{OH}$ and $\mathrm{NO}_{3}$ radicals and temperature (Gao et al. 1996). The MSA mass concentrations are $0.21,0.61$, and $0.61 \mathrm{\mu g} \mathrm{m}^{-3}$ in $\mathrm{PM}_{10}$ in $\mathrm{AD}, \mathrm{HMNC}$, and HKP, respectively, and 0.20, 0.48 , and $0.17 \mu \mathrm{g} \mathrm{m}^{-3}$ in $\mathrm{PM}_{2.5}$ in $\mathrm{AD}, \mathrm{HMC}$, and $\mathrm{HSPC}$, respectively. The MSA mass concentration varies in the order $\mathrm{HMNC}>\mathrm{HKP}>\mathrm{AD}>\mathrm{HSPC}$, while the $\mathrm{NO}_{3}{ }^{-}$mass concentration varies in the order HSPC $>\mathrm{AD}>\mathrm{HKP}>$ HMNC. MSA can be used to track the contribution of biogenic $\mathrm{SO}_{4}{ }^{2-}$ to the total nss- $\mathrm{SO}_{4}{ }^{2-}$; the ratio MSA/ nss- $\mathrm{SO}_{4}{ }^{2}$ represents the biogenic contribution. The ratio ranges from $1.4 \%$ to $9.2 \%$ for $\mathrm{PM}_{10}$ and from $0.68 \%$ to 9.5\% for $\mathrm{PM}_{2.5}$ collected during the campaign. The ratio is $5.4 \%, 3.3 \%$, and $5.8 \%$ for $\mathrm{PM}_{10}$ in $\mathrm{AD}, \mathrm{HMNC}$, and HKP, respectively, and $6.1 \%, 3.6 \%$, and $0.83 \%$ for $\mathrm{PM}_{2.5}$ in $\mathrm{AD}, \mathrm{HMC}$, and $\mathrm{HSPC}$, respectively. The ratios reported in previous studies vary widely according to the seasons and geographical locations. Chen et al. (2012) reported a ratio of $0.2 \%-6 \%$ in tropical regions, $6 \%-12 \%$ in unpolluted mid-latitudes, and 15\%-93\% near coastal Antarctica. Gao et al. (1996) observed a biogenic contribution of 10\%-19\% over the East China Sea for MarchJun. Arimoto et al. (1996) reported that marine biogenic sources accounted for $3.6 \%$ and $10.9 \%$ at the eastern and western sides of Jeju Island around the Yellow Sea, respectively. Zhang et al. (2013) also estimated the contribution of biogenic nss- $\mathrm{SO}_{4}{ }^{2-}$ to be $12 \%$ over the North Yellow Sea in the spring season (April 23-May 5, 2007). The differences between this study and previous ones may be explained by the differences in the sampling periods and locations as well as the seasonal variation in MSA concentration, at least partially. For example, Mukai et al. (1995) found that the maximum (minimum) biogenic $\mathrm{SO}_{4}{ }^{2-}$ occurred in the spring and early summer (winter) seasons. Even though the observation regions over the Yellow Sea were substantially affected by anthropogenic pollutants from Asia, the local biogenic nss- $\mathrm{SO}_{4}{ }^{2-}$ cannot be ignored, especially in the spring and early summer seasons, when biological activities are elevated. In addition, estimations of biogenic contributions include considerable uncertainties, as the MSA formation in aerosols from DMS must consider a number of factors, such as the formation time of DMS by nutrient-fed phytoplanktons in the Yellow Sea, and the reaction processes of $\mathrm{NO}_{3}$

Table 5 Correlation coefficient matrix aerosol samples in $\mathrm{PM}_{10}$ using PMS over the Yellow Sea during KORUS-AQ 2016

\begin{tabular}{|c|c|c|c|c|c|c|c|c|}
\hline & MSA & $\mathrm{nss}-\mathrm{SO}_{4}{ }^{2-}$ & $\mathrm{NO}_{3}{ }^{-}$ & $\mathrm{NH}_{4}^{+}$ & $\mathrm{Na}^{+}$ & $\mathrm{Mg}^{2+}$ & nss- $\mathrm{K}^{+}$ & nss- $-\mathrm{Ca}^{2+}$ \\
\hline MSA & 1.00 & & & & & & & \\
\hline nss-SO ${ }_{4}{ }^{2-}$ & 0.24 & 1.00 & & & & & & \\
\hline $\mathrm{NO}_{3}^{-}$ & 0.19 & -0.01 & 1.00 & & & & & \\
\hline $\mathrm{NH}_{4}^{+}$ & 0.34 & 0.84 & 0.47 & 1.00 & & & & \\
\hline $\mathrm{Na}^{+}$ & 0.04 & 0.06 & 0.73 & 0.28 & 1.00 & & & \\
\hline $\mathrm{Mg}^{2+}$ & 0.00 & -0.05 & 0.74 & 0.15 & 0.86 & 1.00 & & \\
\hline nss- $\mathrm{K}^{+}$ & -0.05 & 0.29 & 0.56 & 0.39 & 0.46 & 0.59 & 1.00 & \\
\hline nss-Ca ${ }^{2+}$ & 0.01 & -0.21 & 0.72 & 0.08 & 0.44 & 0.76 & 0.44 & 1.00 \\
\hline
\end{tabular}

Correlation coefficients with a statistical significance of $p<0.01$ are listed in bold 
Table 6 Correlation coefficient matrix aerosol samples in $\mathrm{PM}_{2.5}$ using PMS over the Yellow Sea during KORUS-AQ 2016

\begin{tabular}{|c|c|c|c|c|c|c|c|c|}
\hline & MSA & $\mathrm{nss}-\mathrm{SO}_{4}{ }^{2-}$ & $\mathrm{NO}_{3}^{-}$ & $\mathrm{NH}_{4}^{+}$ & $\mathrm{Na}^{+}$ & $\mathrm{Mg}^{2+}$ & nss- $\mathrm{K}^{+}$ & nss-Ca ${ }^{2+}$ \\
\hline MSA & 1.00 & & & & & & & \\
\hline nss-SO ${ }_{4}{ }^{2-}$ & 0.17 & 1.00 & & & & & & \\
\hline $\mathrm{NO}_{3}^{-}$ & -0.02 & 0.54 & 1.00 & & & & & \\
\hline $\mathrm{NH}_{4}^{+}$ & 0.14 & 0.97 & 0.72 & 1.00 & & & & \\
\hline $\mathrm{Na}^{+}$ & 0.06 & 0.05 & 0.56 & 0.12 & 1.00 & & & \\
\hline $\mathrm{Mg}^{2+}$ & 0.29 & 0.25 & 0.34 & 0.21 & 0.54 & 1.00 & & \\
\hline nss- $\mathrm{K}^{+}$ & 0.24 & 0.46 & 0.71 & 0.52 & 0.64 & 0.77 & 1.00 & \\
\hline nss-Ca ${ }^{2+}$ & 0.39 & 0.22 & 0.35 & 0.22 & 0.36 & 0.84 & 0.78 & 1.00 \\
\hline
\end{tabular}

Correlation coefficients with a statistical significance of $p<0.01$ are listed in bold

radicals after leaving terrestrial anthropogenic sources. For more quantitative estimates of the MSA trend over the Yellow Sea, future studies should consider additional variables related to these relevant factors.

\subsubsection{Aerosol Size Distribution (ASD) and Chemical Species in High PM Cases}

The APS observed the aerosol volume number concentration (Nvc) during the cruise (Fig. 10). Figure 10a shows that dust particles in $\mathrm{AD}$ increase the $\mathrm{Nvc}$ in the diameter range above $2.5 \mu \mathrm{m}$. Asian dust mostly affects the particle above $2.5 \mu \mathrm{m}$ and Haze does it below $2.5 \mu \mathrm{m}$ in Korea (Cho et al. 2013). In Fig. 10a, the increased the Nvc above $2.5 \mu \mathrm{m}$ is from Asian dust. Figure 10b shows the
ASD in HMNC. The Nvc rapidly increased in the diameter range below $1 \mu \mathrm{m}$ owing to the haze effects, while the Nvc increased slightly in the diameter range of $1-4 \mu \mathrm{m}$ owing to the sea salt effects. The sea salt concentration depends on the wind speed (Jaeglé et al. 2011). The wind speed in HNMC is the highest among the four cases, with a maximum (minimum) of $12 \mathrm{~m} \mathrm{~s}^{-1}\left(10.8 \mathrm{~m} \mathrm{~s}^{-1}\right)$. Thus, the strong winds during the sampling period contributed to the formation of atmospheric sea salt over the Yellow Sea in HMNC. Figure 10c shows the ASD in HKP. The Nvc below the diameter range of $1 \mu \mathrm{m}$ increased because of the haze. The haze had the strongest influence on the observation in HSPC among the four cases (Fig. 10d).

To identify the main chemical forms in the four cases, we compared the correlation of the ionic species with the ASD.
Fig. 9 Mass concentration of (NH4) $)_{2} \mathrm{SO}_{4}$ and $\mathrm{NH}_{4} \mathrm{NO}_{3}$ using PMS for high aerosol mass concentration cases over the Yellow Sea during the KORUSAQ campaign, 2016

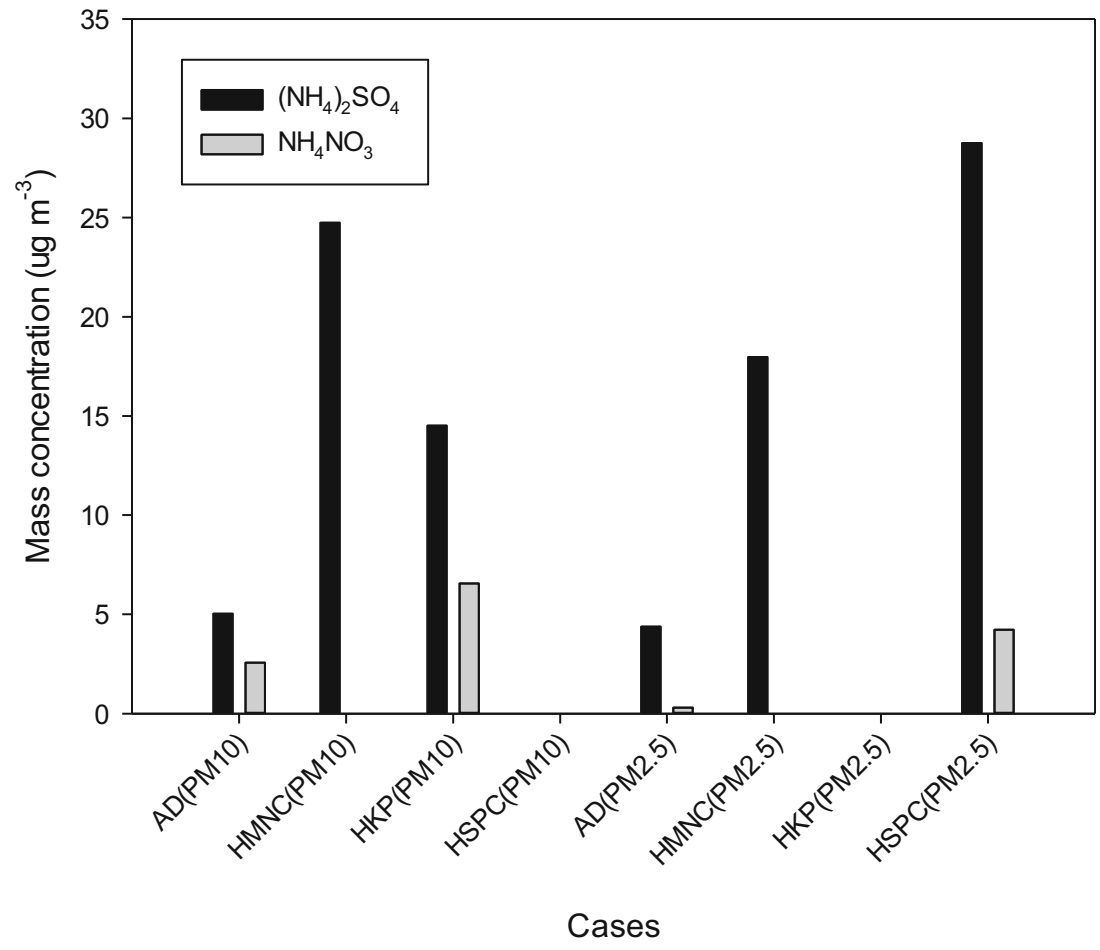



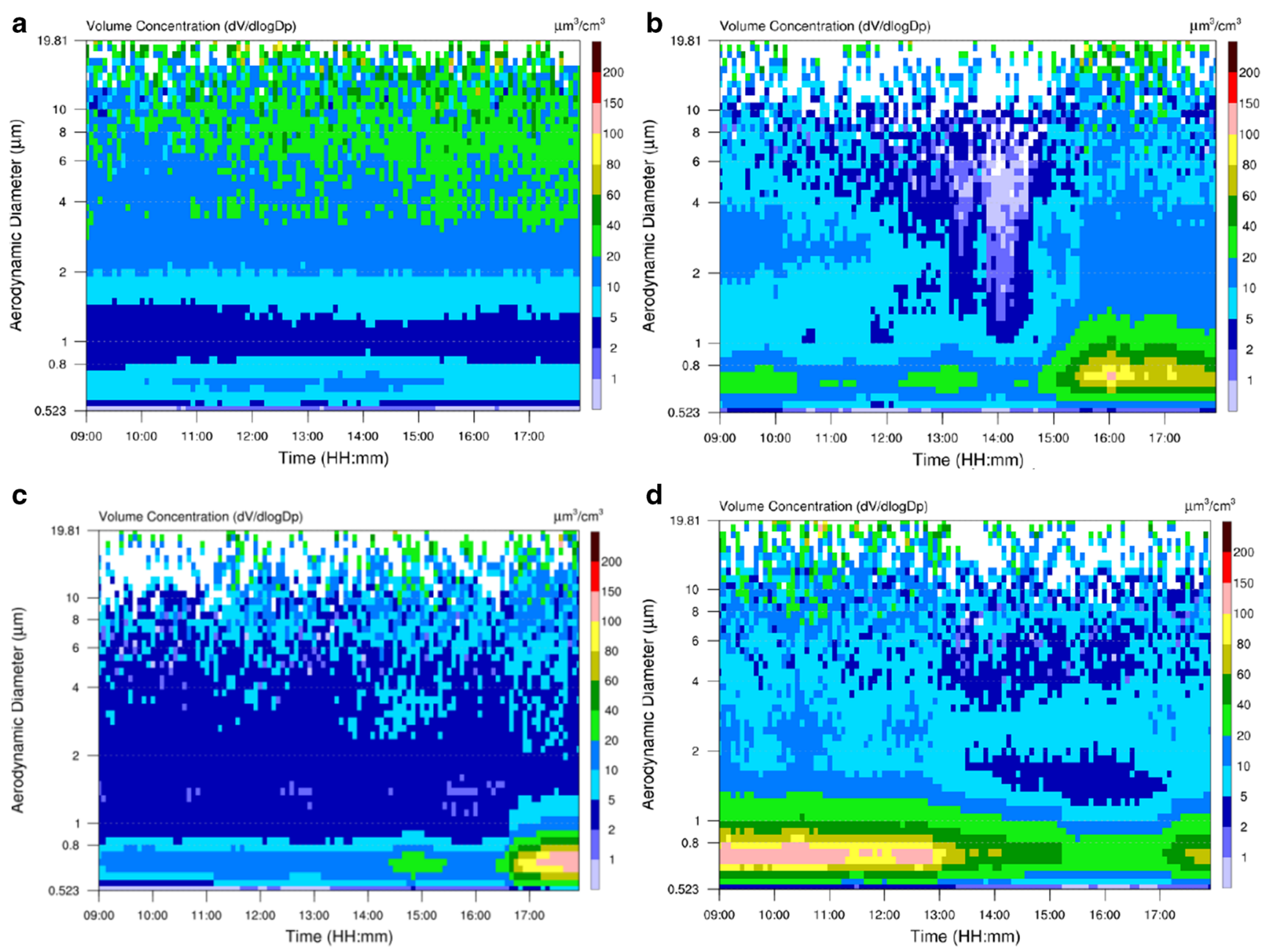

Fig. 10 Aerosol size distribution (dV/dLog) using APS for the four cases during the KORUS-AQ campaign, 2016

Basically, Asian dust mostly affects the particle above 2.5 um and Haze affects it below 2.5 um in Korea (Cho et al. 2013) and then the chemical forms of these ionic species were estimated on the basis of their correlation coefficients and concentrations. In Beijing in 2007, Wang et al. (2005) reported that the main chemical forms are $\mathrm{CaCO}_{3}, \mathrm{CaSO}_{4}$, and $\mathrm{CaNO}_{3}$ in dust events, and $\left(\mathrm{NH}_{4}\right)_{2} \mathrm{SO}_{4}$ and $\mathrm{NH}_{4} \mathrm{NO}_{3}$ in haze events. We also calculated the $\mathrm{CO}_{3}{ }^{-}$, which was the main

Table 7 Relationships between the major ions and the concentration of the main chemical species in $\mathrm{PM}_{10}$ and $\mathrm{PM}_{2.5}$ using PMS over the Yellow Sea during KORUS-AQ 2016

\begin{tabular}{|c|c|c|c|c|c|c|c|c|c|}
\hline & & $\mathrm{PM}_{10}$ & & & & $\mathrm{PM}_{2.5}$ & & & \\
\hline \multirow[t]{4}{*}{ Correlation coefficients } & nss- $\mathrm{Ca}^{2+}-\mathrm{nss}-\mathrm{CO}_{3}{ }^{2-}$ & 0.99 & & & & 0.97 & & & \\
\hline & nss- $-\mathrm{Mg}^{2+}-\mathrm{nss}^{2}-\mathrm{CO}_{3}{ }^{2-}$ & 0.89 & & & & 0.93 & & & \\
\hline & $\mathrm{NH}_{4}^{+}-\mathrm{NO}_{3}^{-}$ & 0.47 & & & & 0.72 & & & \\
\hline & $\mathrm{NH}_{4}{ }^{+}-\mathrm{SO}_{4}{ }^{2-}$ & 0.84 & & & & 0.97 & & & \\
\hline \multicolumn{2}{|l|}{ Observation cases } & $\mathrm{AD}$ & HMNC & HKP & HSPC & $\mathrm{AD}$ & $\mathrm{HMNC}$ & HKP & HSPC \\
\hline \multirow[t]{4}{*}{ Concentration $\left(\mu \mathrm{gm}^{-3}\right)$} & $\mathrm{CaCO}_{3}$ & 3.28 & 0.91 & 0.98 & N/A & 0.33 & 0.26 & N/A & 0.42 \\
\hline & $\mathrm{MgCO}_{3}$ & 0.92 & 0.45 & 0.32 & N/A & 0.10 & 0.25 & N/A & 0.25 \\
\hline & $\mathrm{NH}_{4} \mathrm{NO}_{3}$ & 2.56 & - & 6.56 & N/A & 0.30 & - & N/A & 4.23 \\
\hline & $\left(\mathrm{NH}_{4}\right)_{2} \mathrm{SO}_{4}$ & 5.04 & 24.74 & 14.51 & N/A & 4.38 & 17.98 & N/A & 28.75 \\
\hline
\end{tabular}

Correlation coefficients with a statistical significance of $p<0.01$ are listed in bold

N/A, Missing data, -, Not calculated 
Fig. 11 Mass concentration of sea salt using PMS for high aerosol mass concentration cases over the Yellow Sea during the KORUS-AQ campaign, 2016

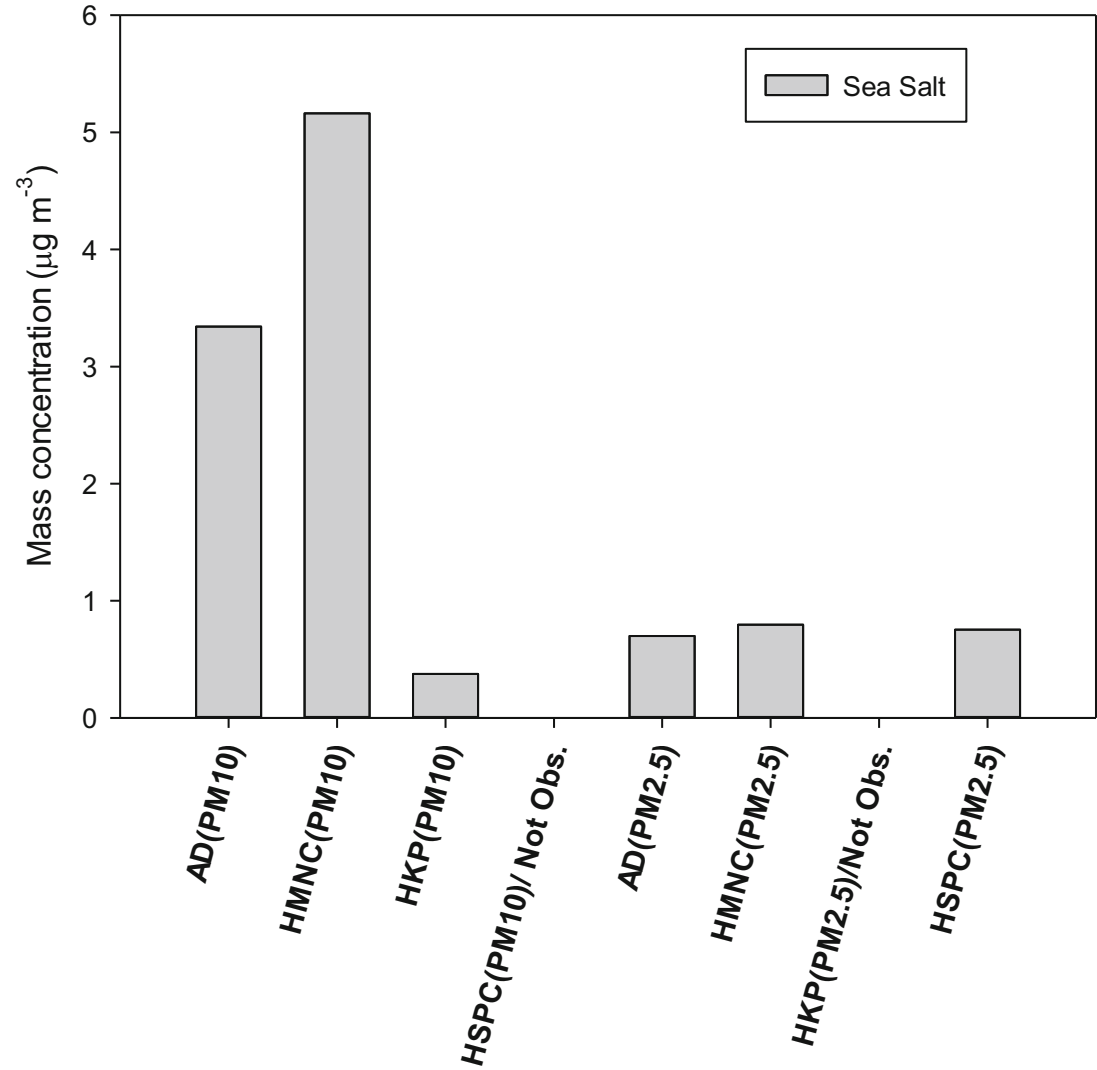

chemical form in $\mathrm{AD}$. The $\mathrm{CO}_{3}{ }^{-}$was not directly analyzed by the IC in the collected samples. We used the method of Kchih et al. (2015) for estimating the $\mathrm{CO}_{3}{ }^{-}$as follows:

$\left[\mathrm{CO}_{3}^{-}\right]=2.5\left[\mathrm{Mg}_{(\mathrm{s})}\right]+1.5\left[\mathrm{Ca}_{(\mathrm{s})}\right]$

$\mathrm{CaCO}_{3}$ and $\mathrm{MgCO}_{3}$ are calculated by the equivalent molar concentrations of $\mathrm{Ca}^{2+}, \mathrm{Mg}^{2+}$, and $\mathrm{CO}_{3}{ }^{2-}$, which are from continental sources. The nss- $\mathrm{CO}_{3}{ }^{-}$is estimated using Eq. (3) with nss- $\mathrm{Ca}^{2+}$ and nss- $\mathrm{Mg}^{2+}$. In Tables 5 and 6 , the nss- $\mathrm{SO}_{4}{ }^{2-}$ is very weakly correlated with the nss- $\mathrm{Ca}^{2+}$, indicating that during the KORUS-AQ campaign, $\mathrm{CaSO}_{4}$ was not the main chemical over the Yellow Sea and the most of the $\mathrm{NO}_{3}{ }^{-}$is contained in $\mathrm{PM}_{10}$ (See Fig. 9), and that nss- $\mathrm{CO}_{3}{ }^{-}$is closely correlated with $\mathrm{Na}^{+}, \mathrm{Mg}^{2+}$, and nss-Ca ${ }^{2+}$ in $\mathrm{PM}_{10}$. Thus, during the KORUSAQ campaign, $\mathrm{NO}_{3}{ }^{-}$was present in $\mathrm{PM}_{10}$ over the Yellow Sea. Table 7 summarizes the relationships between the major ions and the concentrations of the main chemical species in the $\mathrm{PM}_{10}$ and $\mathrm{PM}_{2.5}$ samples over the Yellow Sea. $\mathrm{CaCO}_{3}$ and $\mathrm{MgCO}_{3}$ are the clearly dominant species for $\mathrm{AD}$. In addition, coarse nitrate particles in $\mathrm{PM}_{10}$ can be produced via the reaction of gaseous nitric acid with mineral aerosols, because $\mathrm{NO}_{3}{ }^{-}$is well correlated with $\mathrm{Na}^{+}, \mathrm{Mg}^{2+}$, and nss-Ca ${ }^{2+}$, and weakly correlated with $\mathrm{NH}_{4}{ }^{+}$in $\mathrm{PM}_{10}$. Thus, the Nvc increases in the diameter range above $2.5 \mu \mathrm{m}$ in $\mathrm{AD}$.

In $\mathrm{HMNC}, \mathrm{RH}$ ranges from $83 \%$ to $90 \%$. The increased Nvc in the diameter range below $1 \mu \mathrm{m}$ was due to haze and mist.
When haze occurred over land, the air polluted with haze induced mist formations over the Yellow Sea. In such an environmental condition, the secondary inorganic aerosols $\mathrm{NH}_{4}{ }^{+}$, nss- $\mathrm{SO}_{4}{ }^{2-}$, and $\mathrm{NO}_{3}{ }^{-}$) exist mainly in the form of $\left(\mathrm{NH}_{4}\right)_{2} \mathrm{SO}_{4}$ and $\mathrm{NH}_{4} \mathrm{NO}_{3}$ in the diameter range below $1 \mu \mathrm{m}$ (RogulaKozłowska et al. 2014). The $\left(\mathrm{NH}_{4}\right)_{2} \mathrm{SO}_{4}$ mass concentration was $24 \mu \mathrm{g} \mathrm{m}^{-3}$, and $\mathrm{NH}_{4} \mathrm{NO}_{3}$ was not present in $\mathrm{HMNC}$ (Fig. 9). Thus, when $\mathrm{RH}$ and the mass concentration of nss$\mathrm{SO}_{4}{ }^{2-}$ are large, $\left(\mathrm{NH}_{4}\right)_{2} \mathrm{SO}_{4}$ is the main component of the particles having a diameter of less than $1 \mu \mathrm{m}$ (Song et al. 2008).

We used $3.27 \times \mathrm{Na}^{+}$for estimation of the sea salt mass concentration for the four cases, as shown in Fig. 11 (Ohta and Okita 1984). The mass concentration of sea salt is the highest in HNMC among the four cases. Sea salt is generally formed as $\mathrm{NaCl}$. The sea salt size distribution ranges from 0.005 to $10 \mu \mathrm{m}$. Thus, $\left(\mathrm{NH}_{4}\right)_{2} \mathrm{SO}_{4}$ and sea salt were the main chemical species in HNMC. The sea salts enhanced the mist in the observation site over the Yellow Sea, because they are hydrophilic particle in high RH (83\% to 90\%) environments.

In HKP and HSPC, the Nvc rapidly increased in the diameter range below $1 \mu \mathrm{m}$ owing to the haze. The main species in both the cases were $\left(\mathrm{NH}_{4}\right)_{2} \mathrm{SO}_{4}$ and $\mathrm{NH}_{4} \mathrm{NO}_{3}$. The mass concentration of $\left(\mathrm{NH}_{4}\right)_{2} \mathrm{SO}_{4}$ is higher than that of $\mathrm{NH}_{4} \mathrm{NO}_{3}$. In particular, $\mathrm{NH}_{4}{ }^{+}$in $\mathrm{PM}_{2.5}$ is better correlated with $\mathrm{NO}_{3}{ }^{-}$than that in $\mathrm{PM}_{10}$ (Tables 5 and 6). The reactions in which $\mathrm{HNO}_{3}$ replaces water-soluble particulates, such as formate, acetate, and oxalate, are also important formation pathways for fine 
nitrate particles (Tabazadeh et al. 1998). Organic anions may be abundant in fine particles, such as those from biomass burning (Talbot et al. 1988; Andreae et al. 1988). In the future, to understand the generation of fine nitrate particles over the Yellow Sea in the presence of the reaction of gaseous nitric acid with gaseous ammonia, we will require additional details regarding $\mathrm{NH}_{4} \mathrm{NO}_{3}$ chemical reactions of the sampled gaseous nitric acid with gaseous ammonia.

\section{Summary and Conclusions}

This study investigated the water-soluble ionic characteristics of atmospheric aerosols collected over the Yellow Sea during the KORUS-AQ campaign. High aerosol mass concentration cases during the campaign were classified in terms of the aerosol size distribution and mass concentration: "Asian dust" and "haze" for the hourly mean $\mathrm{PM}_{2.5} / \mathrm{PM}_{10}$ ratio below $40 \%$ and over $80 \%$, respectively. Backward trajectories corresponding to each case were analyzed using the HYSPLIT model. On the basis of these criteria and trajectory analyses, the high aerosol concentration cases during the campaign were classified into four groups: AD, HMNC, HKP, and HSPC. After the classification, we analyzed the watersoluble ions in the samples over the Yellow sea.

In four high PM cases, the mass concentration of nss- $\mathrm{SO}_{4}{ }^{2-}$ varies in the order HSPC $>\mathrm{HMNC}>\mathrm{HKP}>\mathrm{AD}$. Thus, most of the nss- $\mathrm{SO}_{4}{ }^{2-}$ over the Yellow Sea in May 2016 came from the Shandong Peninsula and Northeast China. The $\mathrm{NH}_{4}{ }^{+}$mass concentration varies nearly identically to that of nss- $\mathrm{SO}_{4}{ }^{2-}$, except for the differences in the mass concentrations. The mass concentration of $\mathrm{NO}_{3}{ }^{-}$varies in the order $\mathrm{HSPC}>\mathrm{AD}>$ $\mathrm{HKP}>\mathrm{HMNC}$. For the four cases, $\mathrm{NO}_{3}{ }^{-}, \mathrm{Na}^{+}, \mathrm{Mg}^{2+}$, and nss- $\mathrm{Ca}^{2+}$ were mostly contained in $\mathrm{PM}_{10}$. These results suggest that $\mathrm{NO}_{3}{ }^{-}$is mostly combined with $\mathrm{Na}^{+}, \mathrm{Mg}^{2+}$, and nss-Ca ${ }^{2+}$ in $\mathrm{PM}_{10}$ during high aerosol mass concentration events over the Yellow Sea. This implies that ions such as $\mathrm{Mg}^{2+}$ and nss-Ca ${ }^{2+}$ in $\mathrm{PM}_{10}$ among dust particles during $\mathrm{AD}$ reacted more with nitrates than with sulfates from anthropogenic sources in China. In $\mathrm{AD}$ case, the ratio of $\mathrm{NO}_{3}{ }^{-}$to nss-SO $\mathrm{SO}_{4}{ }^{2-}$ in the aerosols showed that mobile (stationary) sources mainly affected $\mathrm{PM}_{10}\left(\mathrm{PM}_{2.5}\right)$. The major chemical species for Asian dust cases over the Yellow sea were $\mathrm{CaCO}_{3}, \mathrm{Ca}\left(\mathrm{NO}_{3}\right)_{2}, \mathrm{Mg}\left(\mathrm{NO}_{3}\right)_{2}$, $\mathrm{Na}\left(\mathrm{NO}_{3}\right)_{2}$, and sea salt. In haze cases (HSPC, HKP, and HMNC) over the Yellow sea, the contributions from stationary sources are high and the major species were $\left(\mathrm{NH}_{4}\right)_{2} \mathrm{SO}_{4}$ and $\mathrm{NH}_{4} \mathrm{NO}_{3}$ in $\mathrm{PM}_{10}$ and $\mathrm{PM}_{2.5}$, respectively.

The MSA mass concentrations are $0.21,0.61$, and $0.61 \mu \mathrm{g} \mathrm{m}^{-3}$ in $\mathrm{PM}_{10}$ in $\mathrm{AD}, \mathrm{HMNC}$, and HKP, respectively, and $0.20,0.48$, and $0.17 \mu \mathrm{g} \mathrm{m}^{-3}$ in $\mathrm{PM}_{2.5}$ in $\mathrm{AD}, \mathrm{HMC}$, and HSPC, respectively. The MSA mass concentration varies in the order $\mathrm{HMNC}>\mathrm{HKP}>\mathrm{AD}>\mathrm{HSPC}$, while the $\mathrm{NO}_{3}{ }^{-}$mass concentration varies in the order HSPC $>\mathrm{AD}>\mathrm{HKP}>$
HMNC. High mass concentrations of methane sulfonic acid (MSA, $\mathrm{CH}_{3} \mathrm{SO}_{3}{ }^{-}$), the main source of natural sulfates over the Yellow Sea, were observed. The concentrations of MSA were found to show an increasing trend over the Yellow Sea in recent years. Biogenic sulfur contributions to the total nss$\mathrm{SO}_{4}{ }^{2-}$ (MSA/nss- $\mathrm{SO}_{4}{ }^{2-}$ ratio) over the Yellow Sea ranged from $1.4 \%$ to $9.2 \%$ in $\mathrm{PM}_{10}$ and from $0.68 \%$ to $9.5 \%$ in $\mathrm{PM}_{2.5}$ during the cruise. Thus, biogenic nss- $\mathrm{SO}_{4}{ }^{2-}$ must be included, especially in the spring and early summer seasons, when biological activities are elevated in Northeast Asia.

In the future, we need to analyze element species such as $\mathrm{Al}$ and $\mathrm{Fe}$ in the aerosols because the element species such as $\mathrm{Fe}$ involves in production of DMS as the source of MSA and understand the more detail changes in various chemical species over the Yellow Sea.

Acknowledgements This research was funded by the Korea Meteorological Administration Research and Development Program “ Development of Asian Dust and Haze Monitoring and Prediction Technology " under Grant (1365003013).

Open Access This article is distributed under the terms of the Creative Commons Attribution 4.0 International License (http:// creativecommons.org/licenses/by/4.0/), which permits unrestricted use, distribution, and reproduction in any medium, provided you give appropriate credit to the original author(s) and the source, provide a link to the Creative Commons license, and indicate if changes were made.

\section{References}

Akimoto, H.: Global air quality and pollution. Science. 302, 1716-1719 (2003)

Andreae, M.O., Browell, E.V., Garstang, M., Gregory, G.L., Harriss, R.C., Hill, G.F., Jacob, D.J., Pereira, M.C., Sachse, G.W., Setzer, A.W., Silva Dias, P.L., Talbot, R.W., Torres, A.L., Wofsy, S.C.: Biomass-burning emissions and associated haze layers over Amazonia. J. Geophys. Res. 93, 1509-1527 (1988)

Arimoto, R., Duce, R.A., Savoie, D.L., Prospero, J.M., Talbot, R., Cullen, J.D., Tomza, U.N., Lewis, F., Ray, B.J.: Relationships among aerosol constituents from Asia and the North Pacific during PEM-west A. Journal of Geophysical Research: Atmospheres. 101, 2011-2023 (1996)

Ayers, G.P., Ivey, J.P., Goodman, H.S.: Sulfate and methanesulfonate in the maritime aerosol at cape grim, Tasmania. J. Atmos. Chem. 4, 173-185 (1986)

Boreddy, S. K. R, and K. Kawamura: A 12-year observation of watersoluble ions in TSP aerosols collected at a remote marine location in the western North Pacific: an outflow region of Asian dust. Atmospheric Chemistry and Physics. 15, (2015). https://doi.org/ 10.5194/acp-15-6437-2015

Calhoun, J.A.: Chemical and isotopic methods for understanding the natural marine sulfur cycle. Ph.D. thesis, Univ. of Washington, Seattle. 86 pp (1992)

Cha, J.W., Ko, H.J., Shin, B., Lee, H.J., Kim, J.E., Ahn, B., Ryoo, S.B.: Characteristics of aerosol mass concentration and chemical composition of the yellow and South Sea around the Korean peninsula using a Gisang 1 research vessel. ATMOSPHERE-KOREA. 26, 357-372 (2016)

Chen, L., Wang, J., Gao, Y., Xu, G., Yang, X., Lin, Q., Zhang, Y. Latitudinal distributions of atmospheric MSA and MSA/nss-SO42 
- ratios in summer over the high latitude regions of the southern and northern hemispheres. Journal of Geophysical Research: Atmospheres. 117, D10306 (2012). https://doi.org/10.1029/ 2011JD016559

Cho, C., Park, G., Kim, B.: An effectiveness of simultaneous measurement of $\mathrm{PM}_{10}, \mathrm{PM}_{2.5}$, and $\mathrm{PM}_{1.0}$ concentrations in Asian dust and haze monitoring. Journal of Environmental Science International. 22, 651-666 (2013)

Ding, Y., Liu, Y.: Analysis of long-term variations of fog and haze in China in recent 50 years and their relations with atmospheric humidity. Sci. China Earth Sci. 57, 36-46 (2014)

Galloway, J.N., Schlesinger, W.H., Levy, H., Michaels, A., Schnoor, J.L.: Nitrogen fixation: Anthropogenic enhancement-environmental response. Glob. Biogeochem. Cycles. 9, 235-252 (1996)

Gao, Y., Arimoto, R., Duce, R.A., Chen, L.Q., Zhou, M.Y., Gu, D.Y.: Atmospheric non-sea-salt sulfate, nitrate and methanesulfonate over the China Sea. Journal of Geophysical Research: Atmospheres. 101, 12601-12611 (1996)

Gao, Y., Arimoto, R., Duce, R.A., Zhang, X.Y., Zhang, G.Y., An, Z.S., Chen, L.Q., Zhou, M.Y., Gu, D.Y.: Temporal and spatial distributions of dust and its deposition to the China Sea. Tellus B: Chemical and Physical Meteorology. 49, 172-189 (1997)

Gaudichet, A., Echalar, F., Chatenet, B., Quisefit, J.P., Malingre, G., Cachier, H., Buat-Menard, P., Artaxo, P., Maenhaut, W.: Trace elements in tropical African savanna biomass burning aerosols. J. Atmos. Chem. 22, 19-39 (1995)

Gu, D., Wang, Y., Smeltzer, C., Liu, Z.: Reduction in NOx emission trends over China: regional and seasonal variations. Environ. Sci. Technol. 47, 12912-12919 (2013)

Han, Z., Ueda, H., Matsuda, K.: Model study of the impact of biogenic emission on regional ozone and the effectiveness of emission reduction scenarios over eastern China. Tellus B: Chemical and Physical Meteorology. 57, 12-27 (2005)

Hsu, S.C., Liu, S.C., Arimoto, R., Liu, T.H., Huang, Y.T., Tsai, F., Lin, F.J., Kao, S.J.: Dust deposition to the East China Sea and its biogeochemical implications. Journal of Geophysical Research: Atmospheres. 114, D15304 (2009). https://doi.org/10.1029/2008JD011223

Huang, T., Zhu, X., Zhong, Q., Yun, X., Meng, W., Li, B., Ma, J., Zeng, E.Y., Tao, S.: Spatial and temporal trends in global emissions of nitrogen oxides from 1960 to 2014. Environ. Sci. Technol. 51, 7992-8000 (2017)

Jaeglé, L., Quinn, P.K., Bates, T.S., Alexander, B., Lin, J.T.: Global distribution of sea salt aerosols: new constraints from in situ and remote sensing observations. Atmos. Chem. Phys. 11, 3137-3157 (2011)

Kang, C.H., Kim, W.H., Lee, W.: Chemical composition characteristics of precipitation at two sites in Jeju Island. Bull. Kor. Chem. Soc. 24, 363-368 (2003)

Katrib, Y., Martin, S.T., Rudich, Y., Davidovits, P., Jayne, J.T., Worsnop, D.R.: Density changes of aerosol particles as a result of chemical reaction. Atmos. Chem. Phys. 5, 275-291 (2005)

Kchih, H., Perrino, C., Cherif, S.: Investigation of desert dust contribution to source apportionment of PM10 and PM2. 5 from a southern Mediterranean coast. Aerosol Air Qual. Res. 15, 454-464 (2015)

Kim, Y.P., Lee, J.H., Baik, N.J., Kim, J.Y., Shim, S.G., Kang, C.H.: Summertime characteristics of aerosol composition at Cheju Island. Korea. Atmospheric Environment. 32, 39053915 (1998)

Kim, J.H., Yum, S.S., Lee, Y.G., Choi, B.C.: Ship measurements of submicron aerosol size distributions over the Yellow Sea and the East China Sea. Atmos. Res. 93, 700-714 (2009)

Ko, H.J., Kang, C.H., Cha, J.W., Ryoo, S.B.: Concentration and pollution characteristics of secondary aerosol components over the Yellow Sea by ship-borne observation in spring, 2015. ATMOSPHEREKOREA. 27, 29-40 (2017)
Lee, S.B., Bae, G.N., Moon, K.C., Kim, Y.P.: Characteristics of TSP and $\mathrm{PM}_{2.5}$ measured at Tokchok Island in the Yellow Sea. Atmos. Environ. 36, 5427-5435 (2002)

Liu, F., Zhang, Q., Ronald J. d., Zheng, B., Tong, D., Liu Y, Zheng, Y. and He, K.: Recent reduction in NOx emissions over China: synthesis of satellite observations and emission inventories. Environ. Res. Lett. 11, 114002 (2016)

Millero, F.J.: Chemical Oceanography. 3rd ed. CRC Press. 496 pp (2006)

Mukai, H., Yokouchi, Y., Suzuki, M.: Seasonal variation of methanesulfonic acid in the atmosphere over the oki islands in the sea of Japan. Atmos. Environ. 29, 1637-1648 (1995)

Nishikawa, M., Kanamori, S., Kanamori, N., Mizoguchi, T.: Kosa aerosol as eolian carrier of anthropogenic material. Sci. Total Environ. 107, 13-27 (1991)

Ohta, S., Okita, T.: Measurements of particulate carbon in urban and marine air in Japanese areas. Atmos. Environ. 18, 2439-2445 (1984)

Park, J.Y., Lim, H.J.: Characteristics of water soluble ions in fine particles during the winter and spring in Daegu. J. Korean Soc. Atmos. Environ. 22, 627-641 (2006)

Park, K.T., Jang, S., Lee, K., Yoon, Y.J., Kim, M.S., Park, K., Cho, H.J., Kang, J.H., Udisti, R., Lee, B.Y., Shin, K.H.: Observational evidence for the formation of DMS-derived aerosols during Arctic phytoplankton blooms. Atmos. Chem. Phys. 17, 9665-9675 (2017)

Rogula-Kozłowska, W., Klejnowski, K., Rogula-Kopiec, P., Ośródka, L., Krajny, E., Błaszczak, B., Mathews, B., et al.: Air Qual. Atmos. Health. 7, 41-58 (2014)

Simoneit, B. R. T.: Biomass burning - A review of organic tracers forsmoke from incomplete combustion, Appl. Geochem., 17, 129-162(2002)

Song, C.H., Park, M.E., Lee, K.H., Ahn, H.J., Lee, Y., Kim, J.Y., Han, K.M., Kim, J., Ghim, Y.S., Kim, Y.J.: An investigation into seasonal and regional aerosol characteristics in East Asia using modelpredicted and remotely-sensed aerosol properties. Atmos. Chem. Phys. 8, 6627-6654 (2008)

Su, S., Li, B., Cui, S., Tao, S.: Sulfur dioxide emissions from combustion in China: from 1990 to 2007. Environ. Sci. Technol. 45, 8403-8410 (2011)

Tabazadeh, A., Jacobson, M.Z., Singh, H.B., Toon, O.B., Lin, J.S., Chatfield, R.B., Thakur, A.N., Talbot, R.W., Dibb, J.E.: Nitric acid scavenging by mineral and biomass burning aerosols. Geophys. Res. Lett. 25, 4185-4188 (1998)

Talbot, R.W., Andreae, M.O., Andreae, T.W., Harriss, R.C.: Regional aerosol chemistry of the Amazon Basin during the dry season. Journal of Geophysical Research: Atmospheres. 93, 1499-1508 (1988)

Wang, H.J., Chen, H.P.: Understanding the recent trend of haze pollution in eastern China: roles of climate change. Atmos. Chem. Phys. 16, 4205-4211 (2016)

Wang, Y., Zhuang, G., Sun, Y., An, Z.: Water-soluble part of the aerosol in the dust storm season-evidence of the mixing between mineral and pollution aerosols. Atmos. Environ. 39, 7020-7029 (2005)

Wei, Q., Yao, Q., Wang, B., Wang, H., Yu, Z.: Long-term variation of nutrients in the southern Yellow Sea. Cont. Shelf Res. 111, 184-196 (2015)

Yang, G.-P., Zhang, S.-H., Zhang, H.-H., Yang, J., Liu, C.-Y.: Distribution of biogenic sulfur in the Bohai Sea and northern Yellow Sea and its contribution to atmospheric sulfate aerosol in the late fall. Mar. Chem. 169, 23-32 (2015)

Zhang, J., Liu, S.M., Lü, X., Huang, W.W.: Characterizing Asian winddust transport to the Northwest Pacific Ocean. Direct measurements of the dust flux for two years. Tellus B: Chemical and Physical Meteorology. 45, 335-345 (1993)

Zhang, J., Wu, Y., Liu, C.L., Shen, Z.B., Zhang, Y.: Major components of aerosols in North China: desert region and the Yellow 
Sea in the spring and summer of 1995 and 1996. J. Atmos. Sci. 59, 1515-1532 (2002)

Zhang, J., Yu, Z.G., Raabe, T., Liu, S.M., Starke, A., Zou, L., Gao, H.W., Brockmann, U.: Dynamics of inorganic nutrient species in the Bohai seawaters. J. Mar. Syst. 44, 189-212 (2004)

Zhang, H.H., Yang, G.P., Liu, C.Y., Su, L.P.: Chemical characteristics of aerosol composition over the Yellow Sea and the East China Sea in autumn. J. Atmos. Sci. 70, 1784-1794 (2013)
Zhang, Y., Zhang, H.H., Yang, G.P., Liu, Q.L.: Chemical characteristics and source analysis of aerosol composition over the Bohai Sea and the Yellow Sea in spring and autumn. J. Atmos. Sci. 72, 3563-3573 (2015)

Publisher's Note Springer Nature remains neutral with regard to jurisdictional claims in published maps and institutional affiliations. 